\title{
Teoretyczno-badawcze nurty w polskiej kreatologii
}

\begin{abstract}
Abstrakt
W artykule przedstawiono charakterystykę różnorodnych nurtów badań nad twórczością, które wspólnie tworzą kreatologię - zintegrowany zasób wiedzy o twórczości i człowieku twórczym. Autor kolejno omawia nurt badań psychologii twórczości, pedagogiki, teorii zarządzania i marketingu, geografii oraz filozofii, wskazując na ich główne problemy badawcze i dokonania oraz postulując kierunki przyszłych badań. Nurty te w zwięzły sposób przedstawia tabela 1, a stanowisko własne autor prezentuje w zakończeniu, wymieniając 10 założeń teoretyczno-badawczych Łódzkiej Szkoły Pedagogiki Twórczości.
\end{abstract}

Słowa kluczowe: kreatologia, twórczość, kreatywność, nurty badań nad twórczością.

\section{Theoretic-research trends in Polish creatology}

\begin{abstract}
The article presents the characteristics of various trends (approaches) in creativity research, which together form creatology - an integrated resource of knowledge about creativity and creative man. The author discusses in turn the trends in psychology of creativity, pedagogy, management and marketing theory, geography and philosophy, pointing to their main research problems and achievements, and postulating the direction of future research. These trends are demonstrated in a concise manner in Table 1, and the author presents his own approach at the end, listing 10 theoretical and research assumptions of the Lodz School of Pedagogy of Creativity.
\end{abstract}

Keywords: creatology, creativity, creativity research approaches.

\footnotetext{
* Uniwersytet Łódzki, Wydział Nauk o Wychowaniu UŁ.
} 


\section{Wprowadzenie}

Pojęcie „kreatologii”, występujące w tytule tego numeru „Nauk o Wychowaniu” oraz tego artykułu, może budzić określone i uzasadnione obiekcje i wątpliwości. Jest bowiem nowe i nieugruntowane należycie w języku polskim oraz w dyscyplinach naukowych badających twórczość i człowieka twórczego (kreatywnego). Ma również charakter neologizmu i jest zapożyczone z języka angielskiego - creatology, a takie proste zapożyczenia na ogół wywołują negatywne reakcje, nie tylko językoznawców. Nie darząc tego pojęcia jakąś specjalną estymą, muszę jednocześnie stwierdzić, iż na razie nie ma chyba lepszego określenia na nauki o kreatywności i twórczości. Jako nazwa ogólna dla tych wszystkich subdyscyplin, których przedmiot koncentruje się na aktywności twórczej człowieka, a które są reprezentowane przez autorów w tym tomie, kreatologia znalazła już zastosowanie w niektórych tekstach naukowych (Magyari-Beck 1999; Szmidt 2009a) i powoli zdobywa nowe zastosowania naukowe.

Największym, jak można sądzić, zwolennikiem używania pojęcia „kreatologii” jest węgierski naukowiec, filozof, psycholog i pedagog - Istvan Magyari-Beck, emerytowany profesor Uniwersytetu Corvinus w Budapeszcie, wykładający także w uczelniach zagranicznych. Jak twierdzi, pojęcie kreatologii pojawiło się „oficjalnie" po raz pierwszy na Międzynarodowej Konferencji Socjologii Nauki w Budapeszcie w 1977 r. (Magyari-Beck 1996). Konieczność użycia nowego pojęcia na określenie naukowych badań nad twórczością wynikało, jego zdaniem, z ograniczeń badań psychologicznych, które w XX w. usunęły problematykę produktu (wytworu) twórczości z obszaru swoich zainteresowań i skoncentrowały się prawie wyłącznie na zdolnościach twórczych i aspekcie podmiotowym kreatywności. Pojęcie kreatologii miało wypełnić tę lukę i objąć także aspekt atrybutywny twórczości. „Nie można było zgodzić się z tak wąskim rozumieniem kreatywności, która została zredukowana do pewnego rodzaju procesu i zdolności, nawet w obrębie psychologii, i nie miała żadnego uzasadnienia na poziomie kultur i cywilizacji" - pisze autor (1999: 433). Jego głównym zamiarem w upowszechnieniu kreatologii było rozszerzenie obszaru badań naukowych i subdyscyplin zainteresowanych aktywnością twórczą człowieka w jego czterech podstawowych wymiarach (aspektach): procesu twórczego (process), osoby twórcy (person), wytworu (product) oraz uwarunkowań zewnętrznych (press). Twórczością, argumentuje Magyari-Beck, zajmowały się nie tylko psychologia, ale i inne nauki humanistyczne i społeczne, bo twórczość nie jest fenomenem tylko psychologicznym, lecz również społecznym, edukacyjnym, gospodarczym czy kulturowym. Kreatologia rozumiana interdyscyplinarnie może zapobiec nastawieniom redukcjonistycznym, które jego zdaniem, dają o sobie znać w badaniach psychologicznych od lat 50-tych XX w.

Jak twierdzi Magyari-Beck (1996), pojęcie kreatologii na określenie interdyscyplinarnej nauki o twórczości nie znalazło większego uznania wśród czołowych 
badaczy tego zjawiska, zwłaszcza psychologów, choć przyznają oni, że jest potrzebne i może pełnić funkcje scalające różnorodne podejścia teoretyczne i badawcze zainteresowane aktywnością twórczą i jej wynikami. W mojej opinii jedną z przyczyn małej ekspansji kreatologii w krajach zachodnich jest to, iż nazwa została stworzona nie w czołowych uczelniach zachodnich, lecz na Węgrzech i nie ma naukowo-marketingowego wsparcia, jakie mają dominujące współcześnie w psychologii czy socjologii teorie ogólne.

Wydaje się, że kreatologia, zgodnie z założeniem Magyari-Becka (1999), może być rozumiana jako interdyscyplinarna nauka integrująca różnorodne, swoiste podejścia w rozważaniach i badaniach nad procesem twórczym, wytworem twórczości, osobą twórcy oraz uwarunkowaniami społeczno-kulturowymi, w jakich przebiega ta aktywność. W tym sensie kreatologia scala nurty psychologiczne, socjologiczne, pedagogiczne, filozoficzne, antropologiczne czy historyczne i inne, zainteresowane wymienionymi aspektami twórczości, nie pozwalając na przesadną atominizację i rozszczepienie ogólnego fenomenu badawczego na czynniki partykularne dla poszczególnych dyscyplin naukowych, niechętnych do współpracy. „Kreatolog” to osoba syntetyzująca teorie i dorobek empiryczny dotyczący badań nad twórczością, dbająca o to, by - mówiąc metaforycznie - ciągle widzieć las, a nie tylko pojedyncze drzewa w twórczym lesie.

Poniżej prezentuję jedną z takich prób określenia specyfiki nurtów polskiej kreatologii, biorąc za podstawę ich podziału rodzaj dyscypliny naukowej, w której dany nurt (podejście) jest rozwijany. I tak wyróżniam: 1) nurt psychologiczny, a w nim kierunek poznawczy, personalny i rozwojowy; 2) nurt pedagogiczny, a w nim kierunek społeczno-kulturowy, wczesnoszkolny, edukacji artystycznej, pedagogiki specjalnej i resocjalizacji; 3) nurt zarządzania i marketingu; 4) nurt geografii społecznej i geografii miast oraz 5) nurt filozoficzny.

Zdziwienie może budzić fakt, iż nie ma w tej klasyfikacji nurtu historycznego, ale nie jest to pomyłka lub niedopatrzenie - wyrażam przekonanie, iż historycy polscy, choć naturalnie badają przejawy wszelkiej twórczości ludzkiej w toku dziejów, to jednak nie stworzyli żadnej heurystycznie płodnej teorii ogólnej, która mogłaby wzbogacić dorobek kreatologii. Ta kontrowersyjna teza może okazać się czasowa i nietrafna już w najbliższej przyszłości.

Poniżej przedstawiam krótką charakterystykę poszczególnych nurtów polskiej kreatologii i jej kierunków, zwracając uwagę jedynie na najważniejsze i swoiste dla danej dyscypliny tezy oraz najważniejsze, w moim mniemaniu, prace teoretyczne oraz empiryczne. W podsumowaniu prezentuję syntetyczne ujęcie polskiej kreatologii w jej głównych nurtach, ujęte w tabelę 1 . Ponieważ jest to, jak sądzę, pierwsza tego rodzaju próba w polskiej kreatologii, dlatego też może być dyskusyjna i zawierać mocno arbitralne rozstrzygnięcia, warte poprawy i wzbogacenia. 


\section{Nurt psychologiczny}

Polska psychologia twórczości rozwijała się dynamicznie od lat 80. XX w. do początku XXI w., kiedy to - taką wyrażam od jakiegoś czasu opinię - przestała stanowić czołową dyscyplinę kreatologii polskiej. Wcześniej kamieniami milowymi na drodze jej kształtowania się były prace Stefana Szumana, np. Sztuka dziecka (1927) czy $O$ sztuce $i$ wychowaniu estetycznym (1962). Publikacjami, które wydają się być początkiem nurtu psychologicznego w kreatologii, jest Zbigniewa Pietrasińskiego Myślenie twórcze (1969) oraz Andrzeja Strzałeckiego Wybrane zagadnienia psychologii twórczości (1969), po których tematyka twórczości i rozwoju zdolności twórczych zaczęła coraz częściej gościć na łamach czasopism psychologicznych i monografii naukowych. Czerpiąc z dorobku filozofii i heurystyki filozoficznej, psychologowie poszukiwali odpowiedzi na pytania dotyczące głównie aspektu personalnego i procesualnego twórczości:

- Kim jest osoba twórcza? Jakie cechy (właściwości) różnią ją od osoby nietwórczej?

- Czy istnieje syndrom osobowości twórczej i zdolności twórcze różniące się od innego rodzaju sprawności?

- Na czym polega proces twórczy i jakie operacje poznawcze, właściwości emocjonalne i behawioralne angażuje?

- Czy i jeśli tak, to w jaki sposób można nauczać i rozwijać procesy twórcze w poszczególnych dziedzinach twórczości, takich jak sztuka, nauka, wynalazczość, działalność publiczna i inne? W jakich formach - indywidualnych czy grupowych - odbywa się to najlepiej?

To tylko niektóre z głównych pytań wczesnej kreatologii psychologicznej w Polsce, która teoretycznie i badawczo podążała za głównymi nurtami psychologii twórczości na świecie, dziedzicząc zarówno jej zalety, jak i braki (np. zbytnie skoncentrowanie się na związkach pomiędzy inteligencją a twórczością, między procesami poznawczymi a efektywnością twórczą, koncentracją na metodach psychometrycznych w badaniach). Co ciekawe, w miarę wcześnie $\mathrm{w}$ psychologii pojawiły się próby akademickiej syntezy wiedzy o twórczości: Andrzeja Strzałeckiego wspomniane wyżej Wybrane zagadnienia psychologii twórczości (1969), popularyzujące czteroaspektowe postrzeganie tego zjawiska, Tomasza Kocowskiego Szkice z teorii twórczości i motywacji (1991), Witolda Dobrołowicza Psychologia twórczości w zarysie (1982), Józefy Sołowiej Psychologia twórczości (1997), Stanisława Popka Człowiek jako jednostka twórcza (2001), Edwarda Nęcki Psychologia twórczości (2001). Ambicje syntetyzujące mają również późniejsze publikacje psychologów twórczości: Aleksandry Tokarz Dynamika procesu twórczego (2005), praca zbiorowa pod redakcją tej autorki $W$ poszukiwaniu zastosowań psychologii twórczości (2005); Andrzeja Strzałeckiego Psychologia twórczości. Między tradycja a ponowoczesnościq (2003), Stanisława Popka Psychologia twórczości plastycznej (2010), Macieja Karwowskiego Klimat dla kreatywności (2009), którą można 
również zaliczyć do nurtu pedagogicznego, jak i do teorii zarządzania. Kreatologicznym syntezom towarzyszyły liczne prace empiryczne, które od lat 70. XX w. uformowały się w trzy silne kierunki badawcze (zob. Nęcka, Grohman, Słabosz 2006).

Kierunek poznawczy reprezentują psychologowie poznawczy i eksperymentalni, związani z Edwardem Nęcką w Uniwersytecie Jagiellońskim, Andrzejem Strzałeckim w Uniwersytecie im. S. Wyszyńskiego, Anną Matczak w Uniwersytecie Warszawskim, Aliną Kolańczyk w Uniwersytecie Gdańskim i inni. Poszukują oni odpowiedzi na pytanie o naturę procesów twórczych i „czynne” w nich operacje intelektualne. Badają związki pomiędzy zdolnościami twórczymi a jakością generowanych wytworów, wykorzystując coraz liczniejsze narzędzia psychometryczne (testy twórczości), próbują wyjaśnić korelacje pomiędzy wysokim poziomem osiągnięć twórczych a uwagą, pamięcią, ilorazem inteligencji i innymi zmiennymi poznawczymi. Wydaje się, że dwie polskie teorie poznawcze twórczości zasługują na uwagę kreatologów na świecie: koncepcja interakcji twórczej i operacji poznawczych właściwych dla twórczości Edwarda Nęcki (1995) oraz stylów twórczego zachowania Andrzeja Strzałeckiego (1989), które były wielokrotnie poddawane empirycznej weryfikacji na przełomie XX i XXI w. (Łukasik 1999). Znacząca w pewnym momencie dla psychologów twórczości wydała się być teoria rdzeni pojęciowych oraz badania Jerzego Trzebińskiego $(1978,1981)$ nad oryginalnością myślenia. Mechanizmów poznawczych związanych z twórczością i uwagą, pamięcią, zdolnościami wyobrażeniowymi, myśleniem krytycznym i dywergencyjnym, oceną oraz innymi zmiennymi intelektualnymi poszukują inni psychologowie: Magdalena Grohman (Groborz, Nęcka 2003; Groborz 2004), Wiesława Limont $(1994,1996)$, Krzysztof T. Piotrowski (Piotrowski, Grohman 2005), Michał Chruszczewski (2006, 2009). Oryginalną koncepcję systemową (interakcyjną), łącząca wątki poznawcze ze społecznymi, sformułował Michał Stasiakiewicz (1990).

Psychologowie poznawczy ustalili i te wnioski budują trwały dorobek kreatologii, iż nie ma jednej operacji poznawczej odpowiedzialnej za jakość wytworu twórczości, a więc nie ma czynnika T („T jak twórczość”) analogicznego do ilorazu inteligencji (IQ). Twórczość według nich jest fenomenem poznawczym, ale uzależnionym w dużym stopniu od motywacji i decyzji, by dany problem eksplorować w sposób oryginalny, a myślenie twórcze w dużym stopniu zależy od celu, jaki wyznacza sobie podmiot twórczy, i świadomego wykorzystania specyfiki takich operacji, jak kojarzenie, metaforyzowanie, wykorzystywanie analogii czy przekształcanie treści. Przebieg tych operacji może być kontrolowany i nauczany w czasie treningów twórczości, które są przydatne zarówno w szkołach, jak i firmach oraz organizacjach społecznych. Twórczości, twierdzą kognitywiści, da się nauczyć!

Kierunek personalny wydaje się dominować w XXI w. w psychologii twórczości, a jego głównymi reprezentantami są: Stanisław Popek związany przez wiele lat z UMCS, Witold Dobrołowicz, pracujący wiele lat w warszawskiej APS, Aleksan- 
dra Tokarz z UJ, Irena Pufal-Struzik z UJK w Kielcach, Maciej Karwowski (APS i Uniwersytet Wrocławski). Badacze w tym nurcie poszukują odpowiedzi o osobowościowe uwarunkowania aktywności twórczej zarówno na jej najwyższym, jak i niskim poziomie, pytając o związek pomiędzy cechami charakteru a efektywnością twórczą, określonymi właściwościami postawy twórczej a innymi czynnikami personalnego funkcjonowania. Opracowali też popularne techniki pomiarowe, z których na czoło wysuwa się Kwestionariusz Twórczego Zachowania KANH Stanisława Popka (II wyd. 2000), często używany w badaniach psychologicznych i pedagogicznych. Podstawą tego narzędzia jest autorska koncepcja postawy twórczej S. Popka, rozumiana jako zgodna synteza czynnika poznawczego i zdolności heurystycznych oraz czynnika charakterologicznego związanego z nonkonformizmem. Badania psychologów osobowości twórczej, m.in. Krystyny Drat-Ruszczak (1981), Aleksandry Tokarz (1985, 2005), Ireny Pufal-Struzik (2006), Anety Chybickiej (2004), Macieja Karwowskiego (2009a, 2009b; Karwowski (red.) 2009), Michała Chruszczewskiego (2013), Grażyny Mendeckiej (2003, 2009, 2015), kwestionują wiele mitów dotyczących osobowości twórców z różnych dziedzin i swoistości ich charakteru, wpływu rodziny na dorastanie twórców i znaczenia szkoły w tym procesie. Dowodzą też, iż osobowość twórcza to syndrom różnorodnych, często sprzecznych cech, które pozostają w swoistej harmonii u tego samego twórcy i nie skutkują nerwicą lub zaburzeniami zachowania. W tym aspekcie psychologowie twórczości korzystają z teoretycznych ustaleń filozofów. Istnieje względna zgoda, iż na syndrom osobowości twórczej składają się określone właściwości, związane z otwartością umysłu i ciekawością poznawczą, niezależnością i nonkonformizmem, wytrwałością i uporem oraz pasją w działaniu. W różnych dziedzinach twórczości, np. w sztuce i nauce, wybitni twórcy wykazują się różniącymi się zdolnościami i sprawnościami - można mówić zatem o cechach ogólnych osobowości twórczej (takich jak otwartość czy zaangażowanie) oraz cechach swoistych, rozwijanych przez twórców w danej dziedzinie kreatywności (takich jak wrażliwość zmysłowa u artystów i motywacja autonomiczna u naukowców). Najpełniejszą charakterystykę osobowości twórczej, wywiedzioną zarówno z własnych badań, jak i z analizy przeglądowej, opracował Stanisław Popek (2001), który wyróżnił kilkadziesiąt cech poznawczych, wolicjonalnych i działaniowych twórców. W lubelskiej szkole psychologii twórczości (C. Domański, E. R. Bernacka, D. Turska, R. Wiechnik i inni) szczególną uwagę badawczą poświęca się problemom związku twórczości z nonkonformizmem (Bernacka 2004, 2017) oraz eksploracjom biograficznym i genealogicznym (Domański 2004). Rozwiniętą badawczo szkołę biografii twórczej tworzy Anita Całek, autorka wnikliwego studium życia i twórczości Adama Mickiewicza i Juliusza Słowackiego (2012, 2013).

Co ciekawe, do nurtu personologicznego można zaliczyć różne prace teoretyczne i badawcze pedagogów zainteresowanych uwarunkowaniami wewnętrznymi rozwoju kreatywności: Agaty Cudowskiej cykl publikacji poświęconych twórczym orientacjom życiowym $(2004,2014,2017)$, Moniki Wróblewskiej badania nad 
kompetencjami twórczymi osób dorosłych $(2005,2015)$. Do tego grona dołączyła Aleksandra Chmielińska $(2015,2017)$ wykorzystująca w badaniach nieznaną szerzej koncepcję transgresji Georga Simmla i znaną teorię transgresji twórczych Józefa Kozieleckiego oraz teorię beyonders Paula Torrance'a, diagnozująca w formie indywidualnych przypadków wewnętrzne zasoby twórcze innowacyjnych pedagogów (zob. artykuł A. Chmielińskiej w tym tomie).

Do dorobku kreatologii badacze zorientowani personologicznie dodali zweryfikowaną empirycznie wiedzę o głównych właściwościach osób twórczych i zależnościach poszczególnych cech od zmiennych zewnętrznych, ponadto dookreślili zmienność tych cech w zależności od dziedziny twórczości. Niestety, dominacja podejścia psychometrycznego i swoiste zamykanie się na badania w nurcie jakościowym i biograficznym nie pozwala - jak uważam - przedstawicielom tego nurtu stworzyć heurystycznie płodnych teorii osobowości twórczej, które wnosiłyby coś nowego do utrwalonej już psychologicznej wiedzy na ten temat.

Kierunek rozwojowy reprezentują ci psychologowie oraz pedagodzy, którzy penetrują badawczo rozwój zdolności twórczych w ciągu życia, poszukując prawidłowości w tym procesie i określając swoistość poszczególnych etapów (faz) wzrostu sprawności twórczych. Będąc pod silnym wpływem prac Stefana Szumana, a zwłaszcza jego teorii rozwoju zdolności plastycznych dzieci oraz teorii pytań dziecięcych, wykraczali poza horyzont tych koncepcji w oryginalnych projektach badawczych. Za znaczące w tym nurcie badania można uznać prace Doroty Kubickiej $(2000,2003)$ nad procesem twórczym u dzieci, co jest bardzo rzadko podejmowane w psychologii twórczości, podłużne badania zdolności metaforyzacyjnych i myślenia analogicznego u dzieci Wiesławy Limont $(1994,1996,2005)$ oraz jej oryginalną koncepcję rozwoju zdolności plastycznych (1984), Witolda Ligęzy badania nad myśleniem twórczym dzieci $(2005,2017)$. I znów kierunek tych badań został wzbogacony przez pedagogów zainteresowanych dynamiką rozwoju zdolności twórczych: Aleksandra Nalaskowskiego (1998), który twórczo adaptował teorię rozwoju Erika Ericssona do określenia różnic w rozwoju zdolności twórczych, Janinę Uszyńską-Jarmoc $(2003,2007)$, poszukującą prawidłowości w rozwoju myślenia twórczego u dzieci młodszych, oraz Katarzynę Krasoń (2005, 2013; Krasoń i Mazepa-Domagała 2004), która stworzyła oryginalną koncepcję twórczości ekspresyjnej dzieci i jej przejawów w wybranych dziedzinach sztuki.

Badacze nurtu rozwojowego wzbogacili polską kreatologię o wiedzę na temat swoistości procesów twórczych u dzieci i młodzieży, dekonspirując wiele potocznych mitów o naturalnej jakoby kreatywności dzieci, zwracając uwagę na wymiar procesualny twórczości i jego wartości wychowawcze (orientacja na proces w badaniach i edukacji), a przede wszystkim uzasadnili tezę, iż rozwój zdolności twórczych nie odbywa się skokowo lub fazowo, lecz jest ciągłym procesem inkrementalnym, mającym swe kryzysy na różnych progach szkolnych i rzadkie wzloty.

Wśród teoretycznych koncepcji twórczości psychologów polskich nie sposób nie wymienić teorii transgresji twórczych Józefa Kozieleckiego, która de facto może 
być zaliczona do koncepcji społeczno-kulturowych. Autor (Kozielecki 1996, 1997, 2001, 2004, 2008) przez transgresje rozumie działania i akty myślenia, z reguły intencjonalne i świadome, które przekraczają granice dotychczasowych możliwości i osiągnięć materialnych, symbolicznych oraz społecznych człowieka i które stają się źródłem nowych i ważnych wartości pozytywnych oraz negatywnych (Kozielecki 2001: 18). Transgresja niszczy stare struktury i tworzy nowe formy, pozwala przekształcać rzeczywistość i w tym sensie ściśle łączy się z twórczością, a nawet - w przypadku transgresji pozytywnej - może być postrzegana jako jej synonim. Kozielecki wyróżnia transgresje osobiste (typu P) i transgresje historyczne (typu H): pierwsze są nowe i wartościowe z punktu widzenia jednostki lub małej grupy, drugie zaś nowe i wartościowe $\mathrm{z}$ punktu widzenia całych społeczeństw, a nawet ludzkości (wielkie odkrycia i wynalazki, teorie i dzieła sztuki). Widzimy więc, iż transgresje osobiste mają charakter twórczości pierwotnej, potencjalnej lub codziennej, transgresje historyczne - twórczości wybitnej, skrystalizowanej lub eminencyjnej.

Zasadnicze znaczenie ma jednak podział na transgresje ekspansywne i twórcze. Myślenie i czyny twórcze stanowią, zdaniem Kozieleckiego, najbardziej specyficzny rodzaj transgresji, występują w każdej epoce historycznej, w licznych biografiach twórców i w każdym kręgu kulturowym. Transgresje te, zarówno osobiste, jak i historyczne, podejmują również małe dzieci w swych zabawach konstrukcyjnych i zajęciach plastycznych. Podobnie i chorzy psychicznie mogą zdaniem autora uprawiać pewien rodzaj twórczości (szkice, obrazy). „W naszych czasach gęstość transgresji twórczych i innowacyjnych typu P i H jest szczególnie duża. Rozwija się twórczość techniczna i naukowa, powstają nowe instytucje edukacyjne i metody nauczania (...). Projektuje się różne - nie zawsze skuteczne metody kształcenia własnego «ja» (...). Dzięki kreatywności umysłu nieprawdopodobne stało się czymś realnym" (teoria względności, rzeczywistość wirtualna, lot na Księżyc) (tamże: 42).

Empiryczne i teoretyczne rozwinięcie koncepcji transgresji twórczych przedstawiła wspomniana już wcześniej Aleksandra Chmielińska w książce Dynamika transgresji twórczych (2017).

Podsumowanie: psychologowie twórczości i pedagodzy o orientacji psychologicznej podjęli się w ciągu ostatnich 30 lat wielu badań nad funkcjonowaniem twórczym człowieka, odkryli i określili główne właściwości osób twórczych jako jednostek posiadających wiele antynomicznych cech, zdekonspirowali mityczne pojmowanie procesu twórczego jako grę tajemniczych sił boskich (natchnienie, inspiracja muz itp.), podkreślając normalność i specyfikę przebiegu twórczych operacji poznawczych, akcentując przy tym ważność czynnika motywacyjnego w działaniach twórczych, oraz wskazali na pewne, lecz nie uniwersalne, prawidłowości w rozwoju zdolności twórczych w poszczególnych fazach życia człowieka. Wiele pytań ciągle czeka na pogłębioną odpowiedź psychologów (np. jak powstaje bardzo twórcza idea?, jakie są warunki wybitnych osiągnięć w określonych dziedzinach twórczości?, jakie jest znaczenie motywacji zewnętrznej w twórczości 
profesjonalnej?, jak „mierzyć” cechy osobowości twórczej w różnych dziedzinach? itp.). Wydaje się, że po dużej dynamice badań psychologów twórczości na przełomie wieków, od jakiegoś czasu w nowym tysiącleciu obserwujemy zastój, a nawet uwiąd zainteresowań tematyką kreatywności wśród specjalistów tej dyscypliny. Wystarczy powiedzieć, że nie ma w uczelniach polskich katedry psychologii twórczości, a pierwszy zakład psychologii twórczości został założony pod koniec $2017 \mathrm{r}$. przez pedagoga i psychologa Macieja Karwowskiego w Uniwersytecie Wrocławskim.

\section{Nurt pedagogiczny}

Badania pedagogiczne nad twórczością oraz formułowanie koncepcji teoretycznych na temat wychowania do/przez twórczość nie są „wymysłem’ ostatnich lat, kiedy to tematyka kreatywności i jej rozwoju stała się modna i należy do głównych sfer zainteresowań pedagogów. Nie miejsce tu na szczegółowy rys historyczny, któremu poświęciłem dużo miejsca w innej publikacji (Szmidt 2013a), wystarczy wspomnieć, iż postulaty edukacji twórczej głosili już Henryk Rowid, Kazimierz Korniłowicz, Helena Radlińska, Bohdan Suchodolski, Zbigniew Pietrasiński, Józef Kozielecki, Mirosław S. Szymański czy Jan Zborowski (zob. Szmidt 2001a, 2013a). Używając jednak metafory Jamesa Kaufmana (2016), można powiedzieć, że wymienieni pedagodzy i psychologowie oraz wielu innych, żyjących w pierwszej połowie XX w. oraz w latach 60-tych i 70-tych tego wieku, głównie rozmyślali o twórczości, ale jej nie badali naukowo. Innymi słowy, koncepcjom teoretycznym i postulatom edukacyjnym nie towarzyszyły ugruntowane badania empiryczne (może poza: Szymański 1987), których celem byłoby zdiagnozowanie pedagogicznych uwarunkowań rozwoju kreatywności wszystkich kategorii wieku. Wszystko to zmieniło się w ciągu ostatnich 30 lat, zasadne wydaje się więc zdanie, iż pedagogika twórczości w jej trzech funkcjach (badawczej, teoretycznej i aplikacyjnej) znajduje się „w stanie wrzenia”. Powstały zakłady naukowe z pedagogiką twórczości w nazwie (Zakład Metodologii i Pedagogiki Twórczości na warszawskiej APS, Zakład Psychopedagogiki Kreatywności w tej samej uczelni, Zakład Pedagogiki Twórczości w UŁ, który wszedł w skład Katedry Edukacji Artystycznej i Pedagogiki Twórczości w 2018 r., Zakład Pedagogiki Twórczości i Ekspresji Dziecka w UŚ), a badania pedagogiczne nad twórczością i jej aplikacją w edukacji niuansują się i rozwijają w różnorodnych nurtach.

Pedagodzy twórczości stawiają w swoich badaniach pytania dotyczące zarówno aksjologii, etyki i antropologii twórczej, jak i dydaktyki twórczości i pomocy w tworzeniu (zob. Szmidt 2013a: 31-35):

- Jakie są lub mają być cele wychowania do twórczości i konstruowany wzorzec (ideał) w pełni rozwiniętej osobowości (osoby) twórczej? Jakie wartości, cechy, postawy i umiejętności mają wyznaczać i ukierunkowywać cele tych oddzia- 
ływań i co - jakie racje filozoficzne, psychologiczne, społeczne, ekonomiczne itd. - uzasadniają te cele? Jakie są źródła tych celów i argumenty uzasadniające konieczność formułowania celów kreatywnych we współczesnym świecie i we współczesnej edukacji? Tego rodzaju pytania możemy zaliczyć do aksjologii lub teorii pedagogiki twórczości.

- W jaki sposób - jakimi metodami i narzędziami badawczymi - badać, diagnozować, rozpoznawać potencjalne i urzeczywistnione zdolności twórcze osób wszystkich kategorii wieku? Z jakich przesłanek teoretycznych wywodzą się te metody i jakie są ich źródła empiryczne? Jakie metody i narzędzia diagnostyczne stosować w celu ewaluacji efektywności zajęć twórczych i innowacji pedagogicznych? Które z tych sposobów są bardziej trafne, rzetelne i praktyczne, i pozwalają przewidzieć rozwój aktywności twórczej badanych w późniejszym wieku? Jak konstruować takie narzędzia badawcze? Tego rodzaju pytania możemy zaliczyć do metodologii badań pedagogiki twórczości.

- W jaki sposób - jakimi metodami dydaktycznymi (terapeutycznymi, treningowymi itp.) - pobudzać potencjalne zdolności twórcze uczniów i wychowanków w różnym wieku? Jak rozwijać obudzone już zdolności twórcze, podnosić je na wyższy poziom lub poddawać kulturowej sublimacji? W jaki sposób pomagać uczniom przenosić wyuczone umiejętności do codziennego życia i praktyki zawodowej? Jakie metody i zadania dydaktyczne są najbardziej efektywne w tym procesie? Pytanie to należy do dydaktyki twórczości (psychodydaktyki kreatywności). Możemy do tej grupy pytań zaliczyć bardziej szczegółowe kwestie, takie jak:

○W jakich warunkach psychodydaktycznych powinien odbywać się proces nauczania twórczości? Jakie cechy klimatu szkolnego (atmosfery) sprzyjają pobudzaniu i rozwijaniu sprawności twórczych, a jakie im szkodzą (problem stymulatorów i inhibitorów twórczości)?

o Jakie cechy i umiejętności powinien posiadać dobry pedagog twórczości?

o Jakie znaczenie w nauczaniu twórczości ma współzawodnictwo i rywalizacja, konkursy i olimpiady wiedzy?

o Czy nauczanie twórczości wymaga stosowania swoistych, specyficznych dla dydaktyki twórczości, środków nauczania (aparatury, narzędzi itp.)? Jeśli tak, to jakie narzędzia są najbardziej efektywne, jak je konstruować i stosować?

Pedagodzy twórczości odpowiedzieli na szereg powyższych pytań, na wiele nadal poszukują odpowiedzi w toku licznych badań w różnych nurtach ilościowych i jakościowych, wzbogacających polską kreatologię o nowe koncepcje teoretyczne i wnioski z diagnoz terenowych. Wśród nich wyróżniam trzy główne podejścia, których krótki opis znajduje się poniżej.

Kierunek społeczno-kulturowy reprezentują ci badacze, którzy traktują twórczość i jej rozwój jako fenomen nie tylko jednostkowy i wewnętrzny, zależny od potencjału jednostki, lecz uwikłany w kontekst społeczny i właściwy dla stanu kultury danej społeczności. Twórczość, również twórczość dzieci i młodzieży, 
przebiega według nich w określonym środowisku wychowawczym, może być przez to środowisko budzona, wspierana i rozwijana, lecz może też być przez niego tłamszona, hamowana i karana. Ten nurt badań zapoczątkował Kazimierz Korniłowicz (1926/1976), wskazując na społeczne i kulturalne uwarunkowania kształcenia twórczego młodzieży w placówkach kultury, następnie rozwijali go pedagodzy społeczni (H. Radlińska, A. Kamiński) oraz przedstawiciele pedagogiki kultury i pracy kulturalno-oświatowej (J. Badura, A. Nocuń, J. Szmagalski, M. S. Szymański, D. Jankowski, J. Kargul, J. Gajda, R. Łukaszewicz, J. Zwiernik, D. Kubinowski), a najpełniej opisał i sproblematyzował Roman Schulz w fundamentalnej dla polskiej pedagogiki twórczości pracy Twórczość - społeczne aspekty zjawiska (1990) oraz publikacjach z zakresu innowatyki pedagogicznej (Schulz 1989, 1994, 1996). Dalsze impulsy rozwoju dla tego nurtu dały badania i publikacje Krzysztofa Szmidta (2001a, 2001b, 2013a) oraz Macieja Karwowskiego (2003). Kluczowymi pojęciami tego kierunku badań są: postawa twórcza, środowisko kreatogenne, szkoła wspierająca twórczość (szkoła twórcza), klimat dla kreatywności, stymulatory i inhibitory twórczości, pomoc w tworzeniu, twórczość amatorska i codzienna, twórczość profesjonalna. Pedagodzy społeczni i pedagodzy kultury określili podstawowe warunki środowiskowe, w jakich odbywa się/powinien przebiegać rozwój twórczości osób w różnym wieku, wskazując na rodzaj zadań rozwojowych pobudzających zdolności twórcze (zadania otwarte - dywergencyjne, heurystyczne, niezbyt trudne i niezbyt łatwe) oraz cechy środowiska kreatogennego (otwartość na różnorodność, względna stabilizacja materialna, mecenat i wsparcie społeczne, zachęta do rozsądnego ryzyka poznawczego, przestrzeń dla prezentacji wytworów twórczości, wielość paradygmatów i tolerancja dla przeciwieństw, wolność wewnętrzna twórców i inne). Za szczególnie wzbogacające polską kreatologię uznaję koncepcje pedagogów należących do tego nurtu, dotyczące pomocy w tworzeniu (Szmidt 2001a, 2013a), postawy twórczej oraz szkoły twórczej (Galewska-Kustra 2012), innowacji w edukacji (Przyborowska 2003, 2013), kultury instytucji i organizacji oświatowych wspierających twórczość użytkowników i klientów (Zwiernik 1988; Karwowski 2009a).

Kierunek pedagogiki wczesnoszkolnej (pedagogiki dziecka) to dynamicznie rozwijający się aspekt badawczy pedagogiki twórczości, który został zapoczątkowany przez Annę Trojanowską-Kaczmarską (1970), Jana Zborowskiego (1986), Jerzego Kujawińskiego (red. 1990), Władysława Puśleckiego (1998), a jest twórczo rozwijany przez Jolantę Bonar (2008), Iwonę Czaję-Chudybę (2005, 2013), Janinę Uszyńską-Jarmoc (2003, 2007), Józefę Bałachowicz i Irenę Adamek (Adamek, Bałachowicz (red.) 2013; Bałachowicz, Adamek (red.) 2017), Marzannę MagdęAdamowicz (2005, 2012), Dorotę Klus-Stańską (2000, 2008), Danutę Czelakowską (1996, 2005), Tatianę Kłosińską (2000, 2013), Elżbietę Płóciennik (2010, 2016a, 2016b, 2016c), Jolantę Zwiernik (1996) i innych. Pedagodzy twórczości, będący jednocześnie reprezentantami pedagogiki dziecka i pedagogiki wczesnoszkolnej, badają przejawy aktywności dzieci już od czasów niemowlęctwa, analizują właści- 
wości ich wytworów i prawidłowości (cechy wspólne) w poszczególnych latach życia, szczególną uwagę poświęcając roli opiekunów i nauczycieli oraz ich umiejętnościom wczesnego wykrywania i stymulowania myślenia i działania twórczego dzieci. Wydaje się też, iż najsilniej spośród wszystkich nurtów pedagogicznych rozwijają dydaktykę twórczości, poddając analizie istniejące dyskursy w nauczaniu (D. Klus-Stańska, J. Bonar, M. Wiśniewska-Kin, J. Bałachowicz, I. Czaja-Chudyba, R. Michalak) i konstruując innowacyjne systemy ćwiczeń twórczych dla dzieci oraz eksperymentalnie sprawdzając ich efektywność (np. J. Bonar, E. Płóciennik, M. Just, W. Ligęza, M. Tomaszewska). Dydaktyka twórczości dzieci najmłodszych wydaje się być $w$ Polsce dziedziną rozwiniętą ponad poziom dydaktyk nauczania uczniów starszych, istnieją programy nauczania twórczości o ugruntowanym już zastosowaniu w klasach szkolnych i grupach przedszkolnych (np. programy Żywioły. Lekcje twórczości w nauczaniu zintegrowanym K. J. Szmidta i J. Bonar, Metoda i wyobraźnia E. Płóciennik i M. Just, Krok $w$ kierunku kreatywności M. Jąder, Podróże - skarby przygoda J. Uszyńskiej-Jarmoc, Kraina kreatywności D. Krzywoń), tworzone są również nowe (np. Trening twórczego myślenia D. Klimkiewicz, Myślanki W. Ligęzy i współpracowników). W nurcie tym ciągle aktualny jest problem statusu twórczości dzieci oraz licznych mitów jej dotyczących, które ciągle wydają się być żywe wśród zarówno nauczycieli, jak i artystów czy rodziców, a swą popularność zawdzięczają romantycznej wizji twórczego dziecka, zrodzonej w czasach Nowego Wychowania i pod wpływem psychologii humanistycznej (zob. Wojnar 2008; Szmidt 2009b).

Pedagogika sztuki niejako w sposób naturalny zajmowała się twórczością dzieci, zwłaszcza twórczością artystyczną, widząc w niej ważny czynnik rozwojowy, prowadzący do późniejszych, bardziej wysublimowanych form aktywności artystycznej, bądź jako swoisty i odrębny okres autentycznej, naturalnej i spontanicznej kreatywności dzieci (Trojanowska-Kaczmarska 1971). To w tym nurcie zrodziło się pojęcie sztuki dziecka, które przez wiele lat dominowało nad pojęciem twórczości dziecka, jako nazwa dla swoistej, różniącej dziecko od dorosłego, ale ważnej z punktu widzenia rozwoju, fazy twórczości, głównie plastycznej. Pedagodzy sztuki (wychowania estetycznego) traktowali twórczość dziecka jako cel wychowania oraz jego środek, akcentując dwa kierunki oddziaływań; wychowanie do sztuki i wychowanie przez sztukę (Wojnar 1984). W pedagogice polskiej XX w., odwołując się najczęściej do koncepcji wychowawczych Herberta Reada i pedagogów francuskich, badacze akcentowali wartość uprawiania sztuki dla samorealizacji jednostki oraz osiągania dobrostanu psychicznego, w czym dołączali do postulatów psychologów humanistycznych, traktując sztukę jako czynnik terapeutyczny, korekcyjny i jednocześnie resocjalizacyjny, a tworzenie dóbr sztuki i kultury jako realizację najwyższych potrzeb ekspresji i wyrażania swoich przeżyć poprzez środki estetycznego wyrazu. Twórczość dzieci, ale i osób innych kategorii wieku, miała więc dla pedagogów sztuki wieloraki sens - była szczytnym celem wychowania, ale i środkiem terapeutycznym i bezpiecznym mechanizmem broniącym człowieka 
przed komercjalizacją, infantylizacją i homogenizacją kultury (B. Suchodolski, I. Wojnar, K. Olbrycht, M. Zalewska-Pawlak, K. Pankowska, U. Szuścik, H. KrauzeSikorska). Szczególny dorobek pedagogów sztuki widoczny jest w zakresie tworzenia koncepcji wychowania plastycznego i estetycznego (W. Limont, S. Popek, U. Szuścik, E. Józefowski), wychowania muzycznego (M. Przychodzińska-Kaciczak, W. Jankowski, W. Sacher), a zwłaszcza dramy i teatru (K. Pankowska, A. Gałązka, K. Witerska). Widać też starania o równomierny rozwój dydaktyki twórczości w tych dziedzinach (W. Karolak, K. Witerska, E. Józefowski, K. Lasocińska). Tym, co wydaje się koncentrować uwagę przedstawicieli tego nurtu w ostatnich latach, są problemy wyrugowania sztuki ze szkoły i mediów publicznych oraz karnawalizacja i infantylizacja kultury (K. Pankowska, M. Zalewska-Pawlak). Bardzo oryginalne podejście do badań zdolności twórczych dzieci rozwija w swych licznych projektach Katarzyna Krasoń $(2005,2013)$, poszukując interdyscyplinarnych środków ekspresji jako czynnika dynamizującego rozwój twórczości dzieci.

Do dorobku polskiej kreatologii pedagodzy sztuki dodali rozwinięte refleksje na temat sztuki dziecka, wyniki badań obrazujące określone fazy rozwoju zdolności twórczych (plastycznych, muzycznych, ekspresyjnych) oraz pogłębione krytyki ewolucji sztuki i kultury oraz wpływu tej ewolucji na aktywność twórczą wychowanków.

Z pedagogiką sztuki wiąże się następny nurt pedagogiki twórczości, który jest dopiero we wstępnej fazie rozwoju. Myślę tu o nurcie pedagogiki specjalnej i resocjalizacyjnej rozpatrujących kwestie twórczości w kontekście pracy korekcyjnej, wspierającej oraz resocjalizacji różnych kategorii podopiecznych. Twórczość w tych subdyscyplinach jest rozpatrywana głównie jako środek oddziaływań wychowawczych mający za zadanie wspierać proces terapeutyczny lub socjoterapeutyczny jako katalizator prowadzących do pozytywnych przemian wewnętrznych i zewnętrznych osób o specjalnych potrzebach edukacyjnych, w tym niepełnosprawnych oraz niedostosowanych społecznie. W tym nurcie swoją szczególną obecność i wpływ generatywny na całą dziedzinę zaznaczyła publikacja Marka Konopczyńskiego Twórcza resocjalizacja (2006), w której autor, na tle krytyki istniejących kierunków oddziaływań resocjalizacyjnych, zarysował nowy model tej pracy, oparty na celowym i systematycznym wykorzystaniu twórczości jako celu i sposobu poprawy funkcjonowania osobistego i społecznego podopiecznych ośrodków wychowawczych, a nawet osadzonych w zakładach karnych. Ten kierunek resocjalizacji akcentuje wartość aktywności twórczej w odzyskiwaniu lub podbudowywaniu utraconego często poczucia własnej wartości i autorstwa, niezbędnego w trudnym powrocie do życia w społeczeństwie. Koncepcji teoretycznej twórczej resocjalizacji jak na razie nie towarzyszą rozbudowane badania empiryczne, wydaje się to wyzwaniem przyszłości. W tym kierunku pedagogiki twórczości coraz bardziej widoczne jest stanowisko pedagogów specjalnych wykorzystujących twórczość jako środek pracy terapeutycznej i rozwojowej z uczniami z niepełnosprawnością intelektualną (Parys 2013) oraz różnymi potrzebami 
edukacyjnymi (Lubińska-Kościółek, Plutecka (red.) 2011). Po pozytywnym rozwiązaniu dylematu, czy osoby wykazujące się tymi symptomami są zdolne do tworzenia, pedagodzy specjalni zajmują się obecnie opisami działań i wytworów twórczości licznych twórców niepełnosprawnych, stosując studia przypadków oraz analizę wytworów, konstruują też programy pomocy tym osobom w tworzeniu. Te ostatnie związane są z dynamicznie rozwijającym się nurtem arteterapii, która powoli emancypuje się w samodzielną subdyscyplinę naukową i kierunek oddziaływań (Szulc 2011; Józefowski 2012; Rudowski 2014). Twórczość i jej dziedziny artystyczne, głównie zaś plastyka, gra teatralna, muzyka, twórcze pisanie, są traktowane przez arteterapeutów, podobnie jak przez pedagogów specjalnych i resocjalizacyjnych, jako środek do poprawy stanu zdrowia psychicznego i fizycznego, stymulator rozwoju osobistego i budowania trwałych zasobów twórczych, pozwalających na dobre życie (Pikała, Sasin 2017). Arteterapeuci mają szczególne dokonania w zakresie konstruowania, wdrażania i opisywania projektów twórczych i programów zajęć dla różnych kategorii odbiorców, gorzej natomiast z badaniami weryfikującymi wartości edukacyjne i terapeutyczne tych projektów. Wydaje się jednak, że nurt arteterapeutyczny lata dynamicznego rozwoju ma dopiero przed sobą.

Omawiany nurt pedagogiki twórczości dodał do polskiej kreatologii wiedzę o twórczości osób niepełnosprawnych i mających problemy z dostosowaniem społecznym, ponadto uzasadnił potrzebę wykorzystania twórczości jako środka terapeutycznego i profilaktycznego oraz rozszerzył samo pojmowanie twórczości jako kategorii egalitarnej.

Podsumowanie: pedagogika twórczości w swych licznych kierunkach teoretyczno-badawczych wydaje się być kierunkiem kreatologii najbardziej dynamicznym w nowym tysiącleciu. Liczne zastępy pedagogów wczesnoszkolnych, społecznych, opiekuńczych, kultury i sztuki, resocjalizacji i terapii badają przejawy twórczości osób we wszystkich kategoriach wieku, zdolnych i niepełnosprawnych, tworząc nowe koncepcje dydaktyki twórczości i pomocy w tworzeniu, które podlegają również weryfikacji w starannych procesach badawczych. Pedagodzy twórczości upowszechnili wśród kreatologów egalitarne rozumienie twórczości, uzasadnili empirycznie konieczność odkrywania i pobudzania zdolności twórczych już od najmłodszych lat życia człowieka, stosując różnorodne podejścia metodologiczne i refleksyjnie badając własną praktykę badawczą. Rośnie samoświadomość metodologiczna pedagogów twórczości i krytyczny ogląd własnej praktyki badawczej (zob. Szmidt (red.) 2009; Modrzejewska-Świgulska (red.) 2016; Karwowski (red.) 2009). Odpowiedziano na wiele pytań dotyczących wychowania do twórczości i problemów związanych z tym procesem, określając kodeksy zasad pedagogicznych i konstruując systemy dydaktyczne. Wydaje się, że pedagogicznym problemem numer jeden polskiej kreatologii pozostaje niewielka liczba ugruntowanych naukowo programów nauczania twórczości młodzieży i osób starszych, w porównaniu z dorobkiem kreatologii światowej, oraz dominacja niektórych tylko technik 
badań zdolności i postaw twórczych, związana z niechęcią do tworzenia technik nowych i oryginalnych, jak również psychometryczny dyktat badawczy w konkursach na granty badawcze, który eliminuje projekty oparte na innych orientacjach empirycznych. Na tym tle bardzo oryginalnie rysują się projekty badawcze wykorzystujące podejście systemowe $\mathrm{w}$ badaniach twórców profesjonalnych oraz koncepcja pracy twórczej Howarda Grubera (M. Modrzejewska-Świgulska, Z. Okraj, w tym tomie), jak również dojrzała koncepcja twórczości codziennej Moniki Modrzejewskiej-Świgulskiej (2014) ${ }^{1}$.

\section{Nurt zarządzania i marketingu}

Problematyka kreatywności pracowników i funkcjonowania zespołów twórczych wydaje się być obecna w tekstach przedstawicieli nauk o zarządzaniu i marketingu już od dawna. Zainteresowania tymi zagadnieniami związane były i nadal są z problemami konkurencyjności rynkowej przedsiębiorstw i tworzeniem innowacji wyprzedzających (innowacje oryginalne), które w ostatnich latach stają się podstawowym warunkiem efektywności firm, a nawet przetrwania ich na globalnym rynku pracy. Wśród coraz liczniejszych publikacji naukowych, dotyczących kreatywności w organizacjach i przedsiębiorstwach zwracają szczególnie uwagę prace należące do trzech nurtów: 1) badań nad twórczymi organizacjami, 2) badań nad charakterem zespołów zadaniowych (twórczych) i zarządzaniem twórczością oraz 3) badań dotyczących twórczego rozwiązywania problemów w praktyce zarządzania i usprawnianiem tej sprawności. Wśród publikacji pierwszego nurtu mamy studium Marka Brzezińskiego (2009) na temat „organizacji kreatywnej”, Ewy Jerzyk i kolegów monografię o kreatywności w biznesie (Jerzyk, Leszczyński, Mruk 2004). Drugi nurt reprezentuje coraz większa liczba prac, np. Anety Sokół (2015) ambitna synteza problematyki zarządzania kreatywnością w organizacjach, Józefa Szopińskiego (2004) badania nad kreatywnością menedżerów i ich funkcjonowaniem w środowisku rodzinnym i koleżeńskim, Agnieszki Wojtczuk-Turek (2008) badania eksperymentalne dotyczące efektywności treningu twórczości wśród studentów SGH w Warszawie czy Jana Fazlagicia (2015) charakterystyka osób kreatywnych w biznesie. Wydaje się, że najbardziej dynamiczny jest trzeci kierunek w tym nurcie, związany z kształceniem umiejętności twórczego rozwiązywania problemów w firmach i generowaniem oryginalnych pomysłów biznesowych. Korzystając z dorobku światowego, autorzy reprezentujący ten nurt upowszechniali i uprzystępniali metody heurystyczne, szeroko stosowane w organizacjach i przedsiębiorstwach - w tym aspekcie przedstawiciele teorii zarządzania stali się pierwszymi dydaktykami twórczości w Polsce. Jana Antoszkiewicza $(1990,1998)$

\footnotetext{
1 Z kronikarskiego obowiązku warto jeszcze wspomnieć o dwóch publikacjach, mających charakter ważnych epizodów, które jednak nie były rozwijane w późniejszym czasie: Teresy Gizy (1998) oraz Anny Sajdak (2008).
} 
publikacje z zakresu metod heurystycznych, Witolda Dobrołowicza (1993) Psychika $i$ bariery wprowadzająca trening abarietyczny, Anny Ujwary-Gil (2004) praca o inwentyce w biznesie czy praca zbiorowa pod redakcją Anny Kosieradzkiej (2013), prezentująca wybrane metody pobudzania kreatywności w organizacjach to dobre przykłady tego dynamicznego kierunku kreatologii biznesowej o charakterze dydaktycznym. Odnotować warto, iż ten ostatni kierunek zagrożony jest zdominowaniem go przez publikacje należące do kultury masowej i reprezentujące poradniki rozwoju kreatywności, określane jako „fast-food creativity” (zob. Szmidt 2011), a więc słabo ugruntowane w określonych koncepcjach teoretycznych lub dydaktycznych.

Problematyka kreatywności pracowników i funkcjonowania organizacji twórczych wydaje się czekać w Polsce na naukową syntezę - autorzy dotychczasowych publikacji znajdują się, jak sądzę, pod zbyt dużym wpływem badaczy z Harvardu lub Cambridge i nie wypracowali, jak dotąd, oryginalnych i swoistych koncepcji teoretycznych, mogących wzbogacić to, co już napisali Teresa Amabile, Michael West czy Tony Proctor, czołowi autorzy kierunku biznesowego w kreatologii światowej. Mimo to do dorobku polskiej kreatologii przedstawiciele tego nurtu dodali wiedzę o funkcjonowaniu organizacji twórczych i twórczych zespołów, o metodach pobudzania zdolności ideacyjnych w praktyce i tworzeniu innowacji, o przekraczaniu trudnych barier w procesach wymyślania i wdrażania pomysłów w biznesie.

\section{Nurt geografii społecznej i geografii miast}

Ten nurt współczesnej kreatologii wydaje się być najmłodszym i dopiero w stanie tworzenia. Związany jest głównie z popularnością jednej teorii - klasy twórczej i twórczych miast Richarda Floridy, wzbogaconej o koncepcje tzw. przemysłów kreatywnych i sektorów twórczych w przemyśle i urbanizacji. Przedmiotem rozważań teoretycznych i nielicznych badań w tym nurcie są czynniki tworzące środowisko twórczych miast oraz wyznaczniki funkcjonowania przedstawicieli klasy twórczej, rozpatrywane na ogół w kontekście rozwoju lokalnego lub kształtowania się tzw. kapitału społecznego i kultury regionów miejskich (studia miejskie - urban studies). Ciągłe dyskusje i polemiki wzbudzają wciąż pojęcia kluczowe tych teorii - „klasa twórcza”, „przemysły kreatywne”, „potencjał kreatywny miast”, „kapitał twórczy”, „bohema miejska” i czynniki tworzące te fenomeny. Najambitniejszą publikacją tego nurtu jest, jak do tej pory, monografia Katarzyny Wojnar (2016) Polska klasa kreatywna krytycznie prezentująca zarówno samą teorię klasy twórczej, jak i badania przemysłów kreatywnych w wybranych miastach polskich. Podobny nurt badań reprezentuje Marek Grochowski (2010).

Polscy geografowie odkryli teorię klasy twórczej i twórczych miast dosyć późno, na pewno później niż pedagodzy czy psychologowie, którzy z teorią Richarda 
Floridy zapoznali się już na początku nowego tysiąclecia w publikacji i referatach autora tego artykułu² (Szmidt 2005), jak również w krytycznej analizie koncepcji tego uczonego, przedstawionej kilkakrotnie (Szmidt 2007, 2013a, 2017).

\section{Nurt filozoficzny}

Na ogół podstawy filozoficzne opisu jakiegoś złożonego zjawiska omawia się na początku, ja jednak ten kierunek w polskiej kreatologii zostawiam na końcu, gdyż - jak sądzę - stanem rozwoju nie dorównuje on opisywanym wcześniej kierunkom. Tę kontrowersyjną w istocie tezę uzasadniam nikłym dorobkiem polskiej kreatologii filozoficznej mającej niewiele oryginalnych, na tle międzynarodowym, publikacji, rzadkością organizowanych debat naukowych na temat ontologicznych, epistemologicznych i antropologicznych aspektów twórczości i brakiem, poza wspomnianymi niżej, oryginalnych dokonań filozofów w tym względzie.

Powyższy sąd może nieco dziwić, gdy zwróci się uwagę na to, że jeden z najlepszych w kreatologii światowej, o ile nie najlepszy, z tekstów filozoficznych o dziejach samego pojęcia twórczości wyszedł spod pióra Władysława Tatarkiewicza w 1975 r. Filozof Adam Bastek (2000) w książce Mit homo creatora uzasadnia tezę o wielowiekowym milczeniu filozofii o twórczości. Pytanie o możliwość tworzenia przez człowieka, a więc o zdolność powoływania do życia czegoś nowego i wartościowego, i twierdząca nań odpowiedź to domena naszych czasów - jest ona charakterystyczna dla trzeciego, według Tatarkiewicza, pojęcia twórczości, jakie powstało w dziejach kultury europejskiej.

Jak wiadomo, Tatarkiewicz (1975) wyróżnił pojęcie twórczości jako działalności Boga (Stwórcy), jako działalności artysty i jako aktywności człowieka generującego wartościową nowość. Przywołany już przeze mnie Adam Bastek twierdzi, iż pojęcie twórczości w antyku nie występuje, ponieważ pojęcie nowości nie mieściło się $\mathrm{w}$ granicach starożytnego sposobu myślenia - a więc w granicach tego, co jest. Twórczości nie ujawnia ani filozofia, ani jakakolwiek terminologia. Grecy nie posługiwali się terminami, które można by uznać za odpowiedniki współczesnego „tworzenia” i „twórcy”, ponieważ, jak stwierdza Tatarkiewicz, nie były im potrzebne. Wyraz poiesis oznaczał „robić”, naśladować czy „wydobywać”. Formuła ex nihilo nie pojawia się również w Starym Testamencie, a łacińskie creatio stało się w średniowieczu częścią creatio ex nihilo i przysługiwało jedynie Bogu. Tworzenie z niczego to przez całe wieki całkowicie boski atrybut, niesprowadzalny do świata rzeczy zrobionych przez człowieka. Przez całe stulecia w dziejach kultury europejskiej nie wspominano o twórczości, bo jej nie zauważano; a nie zauważano, bo jej nie ceniono - doskonałość widziano w Kosmosie.

\footnotetext{
2 Wykład K. J. Szmidta pt. „Dlaczego należy być twórczym? Rozważania o powodach istotnych” na seminarium doktorskim w Wyższej Szkole Humanistyczno-Ekonomicznej w Łodzi - 13.11.02 r. zawierał, jak się wydaje, pierwsze w Polsce omówienie koncepcji R. Floridy.
} 
Dopiero w XVII w., jak twierdzi Tatarkiewicz, termin „twórczość” po raz pierwszy został użyty na oznaczenie czynności człowieka, dokładniej poety. Dokonał tego polski teoretyk poezji i poeta Kazimierz Maciej Sarbiewski w dziele De perfecta poesi. Pisze on, że poeta „na nowo tworzy” i tworzy instar Dei.

Bastek twierdzi więc, że przypisywanie wielkim filozofom starożytnym i nowożytnym zasługi rozważań o twórczości ma jedynie charakter dydaktyczny, jest uwspółcześnieniem i może być rozpatrywane - jakby powiedział Heidegger - jako gwałt interpretacyjny. „(...) wbrew obiegowej strategii interpretacyjnej twórczość nie jest pojęciem towarzyszącym filozofii od jej antycznych początków, pytanie o nią nie należy zatem do tych, które były stawiane "z dawien dawna»" (Bastek 2000: 16). Być może to jest jedna z przyczyn tego, iż filozofowie tak późno zajęli się rozważaniami nad twórczością...

Inne ważne dokonanie filozofa na gruncie kreatologii to Władysława Stróżewskiego Dialektyka twórczości (1983; II wyd. 2007), w której autor dociekliwie analizuje dialektyczny charakter głównie dzieła sztuki i twórczości artystycznej z fenomenologicznego punktu widzenia. Wyjaśniając różnice pomiędzy tworzeniem a stwarzaniem, Stróżewski opisuje kilkadziesiąt dychotomii („linii napięć”) zawartych immanentnie w procesie twórczym, m.in.: determinizm i konieczność, konsekwencja i nieprzewidywalność, poddanie i dominacja, spontaniczność i kontrola, swoboda i rygor, improwizacja i kalkulacja i inne (Stróżewski 2007: 315-433). Istota procesu twórczego to ścieranie się tych opozycji i ich komplementarne współdziałanie $\mathrm{w}$ dialogu, który prowadzi do powstania czegoś zarazem nowego i wartościowego. „Dany proces jest zatem tym bardziej twórczy, im więcej zawiera momentów niesprowadzalności i im lepiej realizuje różnego rzędu wartości w wytworach, do których powstania prowadzi" - pisze wybitny polski filozof (tamże: 440). Badania nad aksjologicznym i „sensotwórczym” aspektem twórczości są problemem, który powinien, jego zdaniem, być podjęty przez przyszłych badaczy.

Te trzy znaczące dla kreatologii stanowiska stanowią oryginalne osiągnięcia filozofów polskich, którzy na temat twórczości wypowiadali się nader rzadko. Z kronikarskiego obowiązku wypada odnotować monografię Janusza Kuczyńskiego (1976) Homo creator. Wstęp do dialektyki człowieka propagującą marksistowski ideał człowieka pracy.

I znów można odnotować jako znaczący wkład do filozofii twórczości koncepcję pedagoga filozofującego Andrzeja Góralskiego (1998, 2003) będącą teorią twórczości mistrza i szkoły nauczania twórczości poprzez wzorotwórcze kontakty z mistrzem, wykorzystujące heurystyki i systemy ćwiczeń twórczych. W ostatnim okresie fundamentalnymi problemami filozofii twórczości zajął się Leszek Kopciuch (2016), koncentrując uwagę na problemie wartości i kryzysu wartości w twórczości, oraz młoda badaczka Monika Chylińska (2016a, 2016b), zainteresowana historią rozważań filozoficznych nad twórczością oraz głównymi dylematami filozoficznymi w analizie fenomenu kreatywności. 
Jako w istocie filozoficzne (antropologiczne) można uznać pogłębione rozważania pedagoga Bohdana Suchodolskiego (1972, 1975, 1976, 1983) na temat twórczego stylu życia i opozycji, na jakie jego realizacja napotyka w egzystencji człowieka. Twórczość w rozszerzonym znaczeniu Suchodolski rozumiał jako styl życia przynoszący człowiekowi radość i spełnienie, będący doświadczaniem wartości nadającym ludzkiej egzystencji sens. Twórczość pozwala, jego zdaniem, na przekraczanie granic, jakie wyznaczają ludziom inne postawy życiowe, zwłaszcza postawa konsumpcyjna, postawa ludyczna i postawa heroiczna. W konsumpcji, jak brzmi słynne sformułowanie Suchodolskiego (1975), człowiek się nieustannie powtarza, w twórczości idzie ku temu, co nowe. Celem postawy konsumpcyjnej, którą Suchodolski przeciwstawia często postawie twórczej, jest dobrobyt. Dobrobyt i wygoda rodzą zapotrzebowanie na jeszcze większy dobrobyt i jeszcze lepsze wygody, a nie na twórczość i kulturę. Cywilizacja konsumpcyjna jest cywilizacją antykreatywną - oto wyraźnie zarysowane stanowisko aksjologiczne Suchodolskiego. We współczesnych czasach koncepcja życia twórczego i produktywnego, związanego z purytańskim etosem pracy, została zdystansowana przez ideologię konsumpcyjną. Pod wpływem rywalizacji grup, mody i reklamy konsumpcja odrywa się od autentycznych potrzeb. Rozwija się za to strategia poszukiwania „pełni życia”, związana z podniesieniem poziomu wygód i przyjemności życiowych, zwiększeniem budżetu czasu wolnego i łatwością podróżowania po świecie. Wolność i autentyczność, cechy życia prawdziwie twórczego, giną w mieliznach rozrywki i kultury masowej. Rozwija się druga, „konkurencyjna” w stosunku do twórczości postawa - postawa ludyczna.

Zagrożeniem dla życia prawdziwie twórczego jest, zdaniem Suchodolskiego, nieograniczony kult techniki i organizacji jako cudownych narzędzi współczesnego człowieka, który między siebie a świat wstawia coraz więcej maszyn. Coraz częściej kultura staje się zawisła od narzędzi i finansów. Słabnie znaczenie wzoru i przykładu w krzewieniu kultury, słabnie znaczenie „pamięci żywej” utrzymującej tradycje. Zanika wartość dojrzewania samorzutnego, rozbudzania wewnętrznych sił przez inspirację i poryw. Powstaje przekonanie, iż tworzenie i krzewienie kultury jest jedynie sprawą organizacji i techniki, sprawą propagandy i rozbudowanych narzędzi działań, że jest czymś, co dzieje się łatwo i szybko. Rozwija się komercjalizacja kultury i przekonanie określane przez Suchodolskiego jako „potok zmienności”. Są to przekonania, w myśl których wszelką trwałość można podać w wątpliwość. Wszystko, co dawne, uznane zostaje za gorsze od teraźniejszego. Następuje wynaturzenie stosunku człowieka do przyszłości i teraźniejszości, przekonanie to każe spoglądać z szacunkiem tylko na rzeczy przyszłe. Rzeczywistość staje się ciągiem rozwojowym, wartość rzeczy mierzona jest upływającym czasem. Tymczasem każda rzecz, wszelki czyn twórczy wartościowane powinny być ze względu na to, czym są, nie czym - jak się spodziewamy - będą. Nie tradycja lub postęp, lecz doskonałość, nie przeszłość lub przyszłość, lecz wieczność stają się miernikiem działań. Suchodolski (1999: 149) pisze: „Chcemy, by wszystkie ludzkie 
dzieła - podobnie jak dzieła sztuki i czyny moralne - posiadały wartość wyłącznie ze względu na to, czym są, czym raz na zawsze zostały uczynione".

Model konsumpcyjnego życia nie uwolnił człowieka od przymusu produkcji, a jedynie pogłębił jego wyobcowanie. Należy zatem, tu docieramy do istotnego celu wychowania do twórczości, przekonać innych, iż dobrobyt jest podstawą wartościowego życia, lecz nie jego jedynym celem. Tu może pomóc, zdaniem Suchodolskiego, koncepcja życia jako twórczości.

Postawa konsumpcyjna uczy człowieka organizować cele istnienia wedle oczekiwanych i pożądanych zaspokojeń. Postawa twórcza pozwala wyjść ponad ten poziom i podejmować działania, które mają wartość samą w sobie, a które prowadzą jednocześnie do wyników mających obiektywne znaczenie dla społeczeństwa, niezależnie od podmiotowych interesów twórcy. Postawa twórcza, w której Suchodolski upatruje celu oddziaływań wychowawczych, ukazuje możliwość takiego życia, w którym człowiek oddaje swe siły wartościom obiektywnym, a jednocześnie urzeczywistnia samego siebie i nie poświęca na ołtarzu przemian, jak w postawie heroicznej (bohaterskiej, rewolucyjnej). Człowiek nowoczesny, do którego Suchodolski adresuje swoje postulaty wychowawcze, przeszedł długą i wieloraką szkołę indywidualizmu, poznał uroki życia „wedle siebie”, dlatego też może odnaleźć w postulatach twórczości dyrektywy ważne i pociągające.

Twórczość jest najwyższą formą działania wśród ludzi i dla ludzi - oto podstawowa teza Suchodolskiego (1975). Inne, niemniej ważne:

- Twórczość likwiduje obawy i lęki, niweluje samotność. W twórczości człowiek odnajduje drogę do wspólnoty ludzkiej i jednocześnie akceptuje swoją wolność.

- Twórczość jest pojednaniem pracy i zabawy (homo faber i homo ludens). Dzięki twórczości praca przestaje być ciężkim trudem, a staje się sposobem życia, jego sensem i źródłem zaangażowania. Zabawa przestaje być standaryzowaną rozrywką, stając się naszą ekspresją.

- Dzięki twórczości przekraczamy granice świata rzeczy, które produkujemy i które konsumujemy, wstępując w wyobrażony świat możliwości, z których wydobywamy rzeczy nowe.

- Dzięki twórczości nasze życie chronione jest od przesytu i zniechęcenia. Realizując twórczy styl życia $\mathrm{z}$ odwagą, przyjmujemy ryzyko dające nam poczucie sensu istnienia.

- Twórczość zapewnia nam wolność, jest to wolność, która nie przeraża i nie ciąży.

Ale koncepcja życia jako twórczości nie jest łatwa w realizacji, głównie z uwagi na antynomiczną naturę procesów twórczych. Suchodolski wydaje się mówić pedagogom, iż człowiek jest istotą wewnętrznie sprzeczną i że każda właściwość, jaką posiada, bywa zaprzeczana przez właściwość przeciwstawną. Walczą w nim tendencje do tego, by być wciąż tym samym i być kimś innym, być biernym i twórczym, żyć w ekspresji i być opanowanym, być tutaj i być daleko, coś czynić ze światem i coś czynić ze sobą. 
Przeszkód w upowszechnieniu się życia twórczego, którym miały zająć się instytucje wychowania humanistycznego, widział Suchodolski wiele. Pytał: „Jeśli człowiek jest rzeczywiście istotą twórczą - homo creator - to dlaczego upowszechnienie zasady twórczego życia napotyka na tak wielkie i trudne do pokonania przeszkody?" (Suchodolski 1983: 164). I odpowiadał, że przeszkody są zakorzenione w naturze ludzkiej.

Czego najbardziej pragną ludzie? Nowości czy powtarzalności? Ryzyka czy pewności? Niepokoju czy spokoju? Zapewne pragną i tego, i tamtego. Ale można sądzić, iż na ogół zajmują postawę, dla której ważne jest wszystko, co znajome, co trwałe, wszystko, co daje poczucie bezpieczeństwa i swojskości. Nowość bywa interesująca, ale raczej niebezpieczna, ponieważ wytrąca ze świata, który ludzie znają i w którym ich życie jest ułożone. Twórcy żyją poza tym kręgiem bezpieczeństwa, bardzo często na pograniczu szaleństwa. Ich dzieła często bywają odrzucane; ale nawet gdy otacza ich uwielbienie, oni sami nie stają się modelem i wzorem życia dla wszystkich. (...) Twórczość jest kategorią życia trudnego. Często wygasa w warunkach ułatwionych.

Polscy filozofowie zainteresowani twórczością i kreatywnością dostarczyli kreatologii ugruntowanej wiedzy na temat rozumienia samego pojęcia twórczości i jego zmiennej historii, w czym wyprzedzili badaczy zagranicznych (W. Tatarkiewicz, A. Bastek), ponadto określili dialektyczną i antynomiczną naturę procesów twórczych oraz dyskusyjny status nowości i wartości dzieła. Podjęli także ważne wątki egalitarności i elitarności, naturalności i sztuczności aktów twórczych oraz pomogli pedagogom określić podstawowe warunki kształcenia do twórczości i realizacji twórczego stylu życia, wykorzystujące heurystyki dydaktyczne (A. Góralski), znaczący kontakt $\mathrm{z}$ mistrzem i napięcie pomiędzy twórczym działaniem a konsumpcją i naśladownictwem (B. Suchodolski). Wypada się jednak zgodzić z Moniką Chylińską (2016b: 139), iż filozofia twórczości to dziedzina naukowa dopiero kiełkująca.

Scharakteryzowane powyżej nurty i kierunki polskiej kreatologii, niektóre szerzej, niektóre tylko pobieżnie, tworzą dorobek nowej subdyscypliny, określanej tutaj jako kreatologia. Jedne nurty wydają się być bardziej rozwinięte i ugruntowane naukowo, mające wiele badań i koncepcji teoretycznych w swoim archiwum dorobku, inne - jak, o paradoksie, filozofia czy socjologia - dopiero „kiełkujące”. Z niejakim zdziwieniem autor tych słów odkrył, że trudno jest wyklaryfikować kierunek socjologii twórczości, choć niektóre publikacje socjologów wydają się podejmować problemy ważne dla kreatologii (np. rozdział o twórczości autorstwa Mariana Golki w książce Socjologia sztuki, 2008). Podobnie i językoznawcy czynią dopiero pierwsze kroki, by zbadać i opisać zjawiska tworzenia literatury, ale przy wykorzystaniu środków badawczych właściwych dla wiedzy o twórczości, a nie o języku. Wypada powtórzyć już raz użytą metaforę Jamesa Kaufmana, iż wielu socjologów kultury i sztuki oraz językoznawców raczej rozmyśla o twórczości niż bada to zjawisko. 
Podsumowując omawiane kierunki polskiej kreatologii, sporządziłem tabelę, w której określam w sposób umowny główne problemy badawcze poszczególnych nurtów oraz podaję ich wybranych przedstawicieli.

Tabela 1. Główne nurty badań polskiej kreatologii i ich przedstawiciele

\begin{tabular}{|c|c|c|}
\hline Kierunek & Główne problemy badań & Przedstawiciele \\
\hline Psychologiczny & $\begin{array}{l}\text { Jaka jest psychologiczna natura } \\
\text { procesów twórczych? }\end{array}$ & \\
\hline - poznawczy & $\begin{array}{l}\text { - Jakie procesy (operacje poznawcze) } \\
\text { biorą udział w twórczości? } \\
\text { - Jaki jest związek między twórczo- } \\
\text { ścią a pamięcią, inteligencją i in- } \\
\text { nymi sprawnościami intelektual- } \\
\text { nymi? } \\
\text { - Czy i w jaki sposób można diagno- } \\
\text { zować i rozwijać kompetencje } \\
\text { poznawcze „czynne” w działaniach } \\
\text { twórczych? }\end{array}$ & $\begin{array}{l}\text { J. Kozielecki, Z. Pietrasiński, } \\
\text { A. Strzałecki, J. Trzebiński, } \\
\text { E. Nęcka, Cz. Nosal, A. Kolań- } \\
\text { czyk, A. Matczak, W. Limont, } \\
\text { W. Dobrołowicz, K. T. Piotrow- } \\
\text { ski, A. Słabosz, M. Grohman, } \\
\text { M. Chruszczewski }\end{array}$ \\
\hline - personalny & $\begin{array}{l}\text { - Jakie są osobowościowe determi- } \\
\text { nanty twórczości na jej różnych } \\
\text { poziomach? } \\
\text { - Czym charakteryzuje się osobowość } \\
\text { twórcza (twórców) w różnych } \\
\text { dziedzinach? } \\
\text { - Jaki jest związek pomiędzy twór- } \\
\text { czością a różnymi cechami osobo- } \\
\text { wości (otwartość, niezależność, za- } \\
\text { angażowanie, odwaga, szczęście } \\
\text { itp.)? }\end{array}$ & $\begin{array}{l}\text { Z. Pietrasiński, S. Popek, } \\
\text { T. Kocowski, A. Gałdowa, } \\
\text { W. Limont, W. Dobrołowicz, } \\
\text { J. Strelau, M. Stasiakiewicz, } \\
\text { I. Pufal-Struzik, A. Tokarz, } \\
\text { M. Karwowski, A. Cudowska, } \\
\text { D. Turska, A. Całek, E. R. Ber- } \\
\text { nacka, C. Domanski, J. Gralew- } \\
\text { ski, I. Lebuda, A. Chmielińska }\end{array}$ \\
\hline - rozwojowy & $\begin{array}{l}\text { - Jakie są prawidłowości (etapy, fazy) } \\
\text { w rozwoju zdolności twórczych? } \\
\text { - Czym charakteryzuje się aktywność } \\
\text { twórcza dzieci i młodzieży na róż- } \\
\text { nych poziomach kształcenia? } \\
\text { - Jakie są warunki pozytywnego } \\
\text { rozwoju zdolności twórczych? }\end{array}$ & $\begin{array}{l}\text { S. Szuman, S. Popek, D. Kubicka, } \\
\text { W. Limont, J. Uszyńska-Jarmoc, } \\
\text { A. Nalaskowski, B. Dyrda, } \\
\text { W. Ligęza }\end{array}$ \\
\hline Pedagogiczny & $\begin{array}{l}\text { Jakie są edukacyjne (wychowawcze) } \\
\text { uwarunkowania rozwoju kreatywności? }\end{array}$ & \\
\hline $\begin{array}{l}\text { - } \text { społeczno- } \\
\text {-kulturowy }\end{array}$ & $\begin{array}{l}\text { - Jakie są środowiskowe, kulturowe i } \\
\text { edukacyjne stymulatory i inhibitory } \\
\text { rozwoju kreatywności? } \\
\text { - Jakie są warunki (cechy) szkoły } \\
\text { twórczej (wspierającej twórczość } \\
\text { uczniów) i twórczego nauczania? }\end{array}$ & $\begin{array}{l}\text { K. Korniłowicz, H. Radlińska, } \\
\text { R. Schulz, D. Jankowski, M. S. } \\
\text { Szymański, D. Ekiert-Oldroyd, } \\
\text { K. J. Szmidt, J. Zwiernik, } \\
\text { R. Łukaszewicz, M. Karwowski, } \\
\text { B. Przyborowska, M. Modrze- } \\
\text { jewska-Świgulska, Z. Okraj }\end{array}$ \\
\hline $\begin{array}{l}\text { - wczesno- } \\
\text { szkolny }\end{array}$ & $\begin{array}{l}\text { - Czym się charakteryzuje aktywność } \\
\text { twórcza dzieci? }\end{array}$ & $\begin{array}{l}\text { J. Zborowski, W. Puślecki, } \\
\text { J. Kujawiński, J. Bonar, }\end{array}$ \\
\hline
\end{tabular}




\begin{tabular}{|c|c|c|}
\hline & $\begin{array}{l}\text { - Jakimi metodami, środkami } \\
\text { i treściami budzić i rozwijać zdol- } \\
\text { ności twórcze dzieci? }\end{array}$ & $\begin{array}{l}\text { K. J. Szmidt, J. Uszyńska-Jarmoc, } \\
\text { D. Klus-Stańska, E. Zwolińska, } \\
\text { M. Magda-Adamowicz, J. Bała- } \\
\text { chowicz, I. Czaja-Chudyba, } \\
\text { D. Czelakowska, T. Kłosińska, } \\
\text { E. Płóciennik }\end{array}$ \\
\hline $\begin{array}{l}\text { - edukacji } \\
\text { artystycznej }\end{array}$ & $\begin{array}{l}\text { - Jakie są cechy twórczości arty- } \\
\text { stycznej (sztuki) dziecka? } \\
\text { - Jak rozwijać ekspresje twórczą } \\
\text { uczniów w różnym wieku w erze } \\
\text { dominacji mediów cyfrowych } \\
\text { i kultury masowej? }\end{array}$ & $\begin{array}{l}\text { S. Szuman, I. Wojnar, B. Sucho- } \\
\text { dolski, A. Trojanowska-Kacz- } \\
\text { marska, K. Pankowska, M. Ma- } \\
\text { licka, K. Krasoń, W. Limont, } \\
\text { M. Zalewska-Pawlak, U. Szuścik, } \\
\text { K. Witerska, K. Lasocińska }\end{array}$ \\
\hline $\begin{array}{l}\text { - pedagogiki } \\
\text { specjalnej } \\
\text { i resocjalizacji }\end{array}$ & \begin{tabular}{|l|} 
- Jakie są i jak się przejawiają \\
zdolności i uzdolnienia twórcze \\
osób o specjalnych potrzebach \\
edukacyjnych? \\
- Czy i jak wykorzystać środki \\
twórcze w procesie resocjalizacji \\
i socjoterapii różnych grup społecz- \\
nych?
\end{tabular} & $\begin{array}{l}\text { Z. Doroszewska, H. Olechno- } \\
\text { wicz, M. Konopczyński, } \\
\text { K. Parys, E. Józefowski, } \\
\text { W. Karolak, W. Szulc }\end{array}$ \\
\hline $\begin{array}{l}\text { Zarządzanie } \\
\text { i marketing }\end{array}$ & \begin{tabular}{|l|} 
- Czym się charakteryzują twórcze \\
organizacje i jak je tworzyć? \\
- W jaki sposób funkcjonują twórcze \\
zespoły zadaniowe i jak rozwijać \\
ich działalność? \\
- Czym się charakteryzuje twórcze \\
rozwiązywanie problemów w pracy \\
firm i jak rozwijać umiejętności \\
wykorzystywania metod TRP \\
w praktyce?
\end{tabular} & $\begin{array}{l}\text { J. Antoszkiewicz, M. Brzeziński, } \\
\text { A. Ujwary-Gil, E. Jerzyk, J. Faz- } \\
\text { lagić, A. Murdoch, A. Sokół, } \\
\text { A. Wojtczuk-Turek, A. Lipka, } \\
\text { J. Szopiński, A. Chybicka, } \\
\text { A. Kosieradzka, E. Stanisławiak, } \\
\text { K. J. Szmidt }\end{array}$ \\
\hline $\begin{array}{l}\text { Geografia } \\
\text { społeczna } \\
\text { i geografia } \\
\text { miast }\end{array}$ & $\begin{array}{l}\text { - Jakie są właściwości twórczych } \\
\text { środowisk i kultur (miast, regio- } \\
\text { nów)? } \\
\text { - Jakie czynniki wpływają pozytyw- } \\
\text { nie i negatywnie na procesy po- } \\
\text { wstawania środowisk kreatogen- } \\
\text { nych? } \\
\text { - W jakich regionach geograficznych } \\
\text { i społecznych rozwijają się dyna- } \\
\text { micznie klasy twórcze? } \\
\end{array}$ & $\begin{array}{l}\text { J. Wojnar, M. Grochowski, } \\
\text { T. Stryjakiewicz }\end{array}$ \\
\hline \begin{tabular}{|l} 
Filozofia \\
\end{tabular} & $\begin{array}{l}\text { - Jaki jest status ontologiczny } \\
\text { i epistemologiczny twórczości? } \\
\text { - Czym jest twórczość jako fenomen } \\
\text { ludzki? Jakie angażuje wartości } \\
\text { i jakie niweluje? } \\
\text { - Jakie są antynomie działania } \\
\text { twórczego i twórczego życia? }\end{array}$ & $\begin{array}{l}\text { W. Tatarkiewicz, W. Stróżewski, } \\
\text { B. Suchodolski, J. Kuczyński, } \\
\text { A. Bastek, A. Góralski, A. Pobo- } \\
\text { jewska, L. Kopciuch, }\end{array}$ \\
\hline
\end{tabular}

Źródło: opracowanie własne. 


\section{Zakończenie: wiele nurtów - jeden cel}

Tak wiele dziedzin wiedzy wcześniej, jak i polską kreatologię cechuje, po wstępnym okresie powstawania i krzepnięcia naukowego, wielość i różnorodność kierunków rozwoju problematyki badań i stosowanych w nich podejść badawczych, opartych na swoistych dla danej subdyscypliny założeniach o naturze kreatywności. Jedne subdyscypliny koncentrują się bardziej na osobie twórcy i jej funkcjonowaniu w środowisku (psychologia, pedagogika), inne na formowaniu działań twórczych i warunkach jego powstania (zarządzanie, marketing, pedagogika artystyczna), inne jeszcze na środowisku, w którym przebiega aktywność twórcza (geografia, pedagogika społeczna). Psychologia twórczości od dawna ogniskuje swe badania głównie na procesach poznawczych odpowiedzialnych za osiągnięcia twórcze oraz formowaniu się osobowości twórczej. Choć jest wiele nurtów współczesnej kreatologii, różniących się od siebie akcentowaniem powyższych aspektów w teoretyzowaniu i badaniu, to jednak cel wydaje się wspólny dla psychologów, pedagogów, geografów, specjalistów zarządzania i ekonomii, filozofów i estetyków - jak najlepsze opisanie, wyjaśnienie i prognozowanie rozwoju zjawisk związanych z kreatywnością człowieka. Poszczególne dokonania przedstawicieli kreatologii powoli zbliżają nas do osiągnięcia, w jakiejś mierze, tego ważnego celu naukowych dociekań. Czas wobec tego na powstanie prawdziwej i rzetelnej naukowo syntezy wiedzy o twórczości i człowieku twórczym.

Na podobną syntezę wiedzy o twórczości, jaką są autorskie książki Jane Piirto (2004), Marka Runco (2014), Keitha Sawyera (2012) czy prace zbiorowe pod redakcją Jamesa Kaufmana i Roberta Sternberga (2010) bądź Jonathana Pluckera (2017), będące w pewnym stopniu realizacją postulatu Istvana Magyari-Becka, polskiemu czytelnikowi wypada jeszcze poczekać. Mimo to można uznać, że stan polskiej kreatologii, w porównaniu do innych krajów, zwłaszcza do obozu dawnych krajów socjalistycznych, budzi uzasadniony optymizm. Kierowany tym optymizmem sformułowałem, jako pedagog społeczny i pedagog twórczości w nurcie społeczno-kulturowym, zwięzłe założenia teoretyczno-badawcze, jakie przyjmują przedstawiciele tzw. Łódzkiej Szkoły Pedagogiki Twórczości (Szmidt 2017a). Założenia te przedstawiam w zakończeniu tego opracowania jako swoiste podsumowanie rozważań i klarowne stanowisko badaczy łódzkich.

\section{Zasady teoretyczno-badawcze Łódzkiej Szkoły Pedagogiki Twórczości}

I. Twórczość i kreatywność są złożonymi fenomenami, które trudno jednoznacznie zdefiniować, ale zdefiniować można. W naszym rozumieniu twórczość to działalność przynosząca wytwory (dzieła sztuki, wynalazki, sposoby postrzegania świata, metody działania itp.) cechujące się nowością i mające pewną wartość (estetyczną, użytkową, etyczną, poznawczą i inną), przynajmniej dla samego podmiotu tworzącego. Kreatywność zaś postrze- 
gamy jako osobowy (personalistyczny) wymiar twórczości, będący złożoną syntezą cech poznawczych, emocjonalnych, motywacyjnych oraz zdolności praktycznych jednostki.

II. Kreatywny jest człowiek, a nie jakiś wytwór jego twórczości. Kreatywność to nazwa dla postawy twórczej, w której myślenie twórcze, motywacja protwórcza oraz działania innowacyjne i zaradność znajdują się w harmonijniej równowadze.

III. Twórczość opisywać i badać można we wszystkich jej czterech aspektach: atrybutywnym, procesualnym, personologicznym i ekologicznym. Dla pedagogiki twórczości szczególne znaczenie ma ten ostatni aspekt, który dotyczy właściwości środowiska wychowawczego stymulującego rozwój zdolności twórczych i postaw innowacyjnych.

IV. Pedagogika twórczości jest dyskursywną refleksją naukową nad edukacyjnymi uwarunkowaniami rozwoju kreatywności osób we wszystkich grupach wiekowych oraz pomocą $w$ tworzeniu. Obejmuje teorie twórczości i pomocy w tworzeniu, metodologię badań nad twórczością oraz dydaktykę twórczości rozumianą jako ugruntowana empirycznie wiedza o metodach budzenia i rozwijania postaw twórczych w ciągu życia.

V. Metody badań pedagogiki twórczości są różnorodne i odwołują się do różnych podejść (paradygmatów) badawczych: ilościowego, jakościowego i mieszanego (mixed method). Podejście ilościowe dobrze służy weryfikacji hipotez ogólnych i szczegółowych oraz diagnozie stanu rozwoju zdolności twórczych różnych grup wiekowych i zawodowych, a także praktyki edukacyjnej w makroskali. Podejścia jakościowe i mieszane spełniają swoje funkcje w budowaniu i weryfikowaniu teorii twórczości i pomocy w tworzeniu, w poszukiwaniu znaczeń aktywności twórczej dla życia i rozwoju człowieka oraz odkrywaniu nowych problemów badawczych.

VI. Szczególne znaczenie przywiązujemy do metod jakościowych, a zwłaszcza badań biograficznych, narracyjnych oraz studium przypadku i badań w działaniu (action research), upatrując w nich sposobów na przezwyciężenie wad i ograniczeń podejścia ilościowego i testów twórczości. Dobrze znając praktykę tworzenia i warsztat twórczości profesjonalnej, wyrażamy przekonanie, że twórczość jest zbyt złożonym zjawiskiem, żeby można było ją rzetelnie i trafnie opisać i wyjaśnić za pomocą 3-minutowego testu niezwykłych zastosowań.

VII. Pedagogikę twórczości postrzegamy jako naukową refleksję nad pomocą w tworzeniu i z jednakową uwagą traktujemy jej funkcje deskryptywną, eksplikacyjną i aplikacyjną. W aktualnej sytuacji tej dyscypliny wiedzy pedagogicznej i biorąc pod uwagę stan edukacji twórczej za szczególnie ważny cel pedagogiki twórczości uznajemy tworzenie i wdrażanie do edukacji dobrze ugruntowanych naukowo programów pomocy w tworzeniu. Sądzimy, iż polskiej pedagogice twórczości nie brak teorii i badań - brak dobrych programów nauczania twórczości. 
VIII. Wśród teorii twórczości za najbardziej heurystycznie płodne uznajemy teorie postaw twórczych oraz teorie społeczno-kulturowe, które rozpatrują twórczość jako złożony fenomen działań jednostki w określonym środowisku społeczno-kulturowym, gospodarczym i wychowawczym. W sporze: samotny geniusz czy środowisko, opowiadamy się za: niesamotny geniusz w przychylnym środowisku.

IX. Wychowanie do kreatywności i nauczanie twórczości traktujemy jako ważne i nader aktualne wyzwanie współczesnej edukacji formalnej i nieformalnej. Postulujemy, by uczynić z nich stały, długotrwały, systematyczny, prowadzony przez profesjonalnych pedagogów twórczości kierunek pracy szkoły i placówek kultury. Spełnienie tego warunku wymaga celowej i systematycznej twórczej pracy u podstaw, a nie ograniczania się do akcji i konkursów.

X. Za podstawową zasadę wychowania do twórczości uznajmy pomoc w tworzeniu, rozumianą zgodnie z korniłowiczowską wykładnią jako zintegrowany proces budzenia uśpionych zdolności twórczych, inspirowania wychowanków do podejmowania działań twórczych i wspierania ich w podnoszeniu ich na wyższy poziom.

Jeśli celem uprawiania nauki jest tworzenie coraz bardziej owocnych teorii o dużej zawartości empirycznej i mocy eksplanacyjnej (wyjaśniającej) oraz aplikacyjnej, a nie mnożenie badań empirycznych, nawet coraz bardziej wyrafinowanych, szerokich i poddawanych rozbudowanym procedurom analizy statystycznej, to wydaje się, że polska kreatologia, a zwłaszcza psychologia twórczości i pedagogika twórczości, powinny zwrócić baczniejszą uwagę na ten pierwszy cel. Mówiąc po staropolsku, badań ci u nas dostatek, dobrych teorii raczej nie!

\section{Bibliografia}

Adamek I., Bałachowicz J. (red.) (2013) Kompetencje kreatywne nauczyciela wczesnej edukacji dziecka, Kraków, Oficyna Wydawnicza „Impuls”.

Antoszkiewicz J. (1990) Metody heurystyczne. Twórcze rozwiq̨zywanie problemów, Warszawa, PWE.

Antoszkiewicz J. D. (1998) Rozwiązywanie problemów firmy. Praktyka zmian, Warszawa, Poltext.

Bałachowicz J., Adamek I. (red.) (2017) Kreatywność jako wymiar profesjonalizacji przyszłych nauczycieli wczesnej edukacji, Warszawa, Wydawnictwo APS.

Bastek A. (2000) Mit homo creatora. Rzecz o złudzeniach nowożytnego humanizmu, Olsztyn, Wydawnictwo Uniwersytetu Warmińsko-Mazurskiego. 
Bernacka R. E. (2004) Konformizm i nonkonformizm a twórczość, Lublin, Wydawnictwo UMCS.

Bernacka R. E. (2017) Predyktory nonkonformizmu pozornego, Lublin, Wydawnictwo UMCS.

Bonar J. (2008) Rozwijanie kreatywności uczniów klas poczq̨tkowych poprzez zadania dydaktyczne w toku kształcenia zintegrowanego, Łódź, Wydawnictwo UŁ.

Brzeziński M. (2009) Organizacja kreatywna, Warszawa, Wydawnictwo Naukowe PWN.

Całek A. (2012) Adam Mickiewicz - Juliusz Słowacki. Psychobiografia naukowa, Kraków, Wydawnictwo UJ.

Całek A. (2013) Biografia naukowa: od koncepcji do narracji. Interdyscyplinarność, teorie, metody badawcze, Kraków, Wydawnictwo UJ.

Chmielińska A. (2016) Portret beyonder jako inspiracja do badań biograficznych w: Biograficzne badania nad twórczościq. Teoria i empiria, M. Modrzejewska-Świgulska (red.), Łódź, Wydawnictwo UŁ, s. 59-69.

Chmielińska A. (2017), Dynamika transgresji twórczych. Studia przypadków pedagogów, Łódź, Wydawnictwo UŁ.

Chruszczewski M. H. (2009) Profile uzdolnień. Intelektualne i osobowościowe składniki uzdolnień plastycznych i muzycznych, Warszawa, Wydawnictwo UW.

Chruszczewski M. H. (2013) Zdolności w akcji, Warszawa, Wydawnictwo UW.

Chybicka A. (2004) Otwarty umysł twórczy, Gdańsk, Wydawnictwo UG.

Chylińska M. (2016a) Wprowadzenie do filozofii twórczości. Uwagi pojęciowe - historia idei - perspektywa interdyscyplinarna, „Roczniki Filozoficzne” 64, nr 2, s. 79-108.

Chylińska M. (2016b), o głównych dylematach filozofii twórczości. Ujęcie syntetyczne z uwzględnieniem badań współczesnych, „Roczniki Filozoficzne” 64, nr 2, s. 108-141.

Cudowska A. (2004) Kształtowanie twórczych orientacji życiowych w procesie edukacji, Białystok, Wydawnictwo Uniwersyteckie Trans Humana.

Cudowska A. (2014) Twórcze orientacje życiowe w dialogu edukacyjnym. Studium teoretyczno-empiryczne, Białystok, Wydawnictwo Uniwersyteckie Trans Humana.

Cudowska A. (2017) Twórcze orientacje życiowe. Zdrowie i dobrostan, Białystok, Wydawnictwo UwB. 
Czaja-Chudyba I. (2009) Jak rozwijać zdolności dziecka?, Warszawa, WSiP.

Czaja-Chudyba I. (2013) Kompetencje krytyczne w twórczej refleksji nauczycieli w: Kompetencje kreatywne nauczycieli wczesnej edukacji dziecka, I. Adamek, J. Bałachowicz (red.), Kraków, Oficyna Wydawnicza „Impuls”, s. 129-155.

Czelakowska D. (1996) Twórczość a kształcenie języka dzieci w wieku wczesnoszkolnym, Kraków, Oficyna Wydawnicza „Impuls”.

Czelakowska D. J. (2005) Stymulacja kreatywności językowej dzieci w wieku wczesnoszkolnym, Kraków, Wydawnictwo Naukowe Akademii Pedagogicznej.

Dobrołowicz W. (1982) Psychologia twórczości w zarysie, Kielce, Wydawnictwo WSP.

Dobrołowicz W. (1993) Psychika i bariery, Warszawa, WSiP.

Domański C. W. (2004) „Metoda genealogiczna” w psychologii twórczości w: Twórczość w teorii i praktyce, S. Popek (red.), Lublin, Wydawnictwo UMCS, s. 147-153.

Drat-Ruszczak K. (1981) Osobowościowe wyznaczniki efektywności w twórczości naukowej, Wrocław, Ossolineum.

Fazlagić J. (2015) Kreatywni w biznesie, Warszawa, Wydawnictwo Poltext.

Galewska-Kustra M. (2012) Szkoła wspierajq̨ca twórczość uczniów. Teoria i przykład praktyki, Toruń, Wydawnictwo Adam Marszałek.

Giza T. (1998) Pedagogika twórczości w pracy nauczycielskiej, Kielce, WSP.

Golka M. (2008) Socjologia sztuki, Warszawa, Difin.

Góralski A. (1998) Wzorce twórczości, Warszawa, Wydawnictwo Naukowe SCHOLAR.

Góralski A. (2003) Teoria twórczości. Eseje filozoficzne i pedagogiczne, Warszawa, Wydawnictwo Akademii Pedagogiki Specjalnej.

Groborz M., Nęcka E. (2003) Cognitive control and creativity: Explorations of generation and evaluation of ideas, "Creativity Research Journal”, 15, (2-3), s. 183-197.

Grochowski M. (2010) Sektor kreatywny w Warszawie, Warszawa, Creative Metropoles.

Grohman M. (2004) Wpływ informacji przypadkowych na proces twórczy: generowanie i interpretacja prostych form graficznych w: Twórczość $w$ teorii i praktyce, S. Popek (red.), Lublin, Wydawnictwo UMCS, s. 113-124. 
Jerzyk E., Leszczyński G., Mruk H. (2004) Kreatywność w biznesie, Poznań, Wydawnictwo Akademii Ekonomicznej.

Józefowski E. (2012) Arteterapia w sztuce i edukacji, Poznań, Wydawnictwo Naukowe UAM.

Karwowski M. (2003) Twórcze przewodzenie, Warszawa, Wydawnictwo Instytutu Przedsiębiorczości i Samorządności.

Karwowski M. (2009a) Klimat dla kreatywności. Koncepcje, metody, badania, Warszawa, Centrum Doradztwa i Informacji Difin.

Karwowski M. (2009b) Zgłębianie kreatywności. Studia nad pomiarem poziomu i stylu twórczości, Warszawa, Wydawnictwo Akademii Pedagogiki Specjalnej.

Karwowski M. (2011) Creativity, Giftedness \& Education, Warszawa, Transgression Publishing House.

Karwowski M. (red.) (2009) Identyfikacja potencjału twórczego. Teoria. Metodologia. Diagnostyka, Warszawa, Wydawnictwo APS.

Kaufman J. C. (2016) Creativity 101, second ed., New York, Springer Publishing Company.

Kaufman J. C., Sternberg R. J. (eds.) (2010) The Cambridge Handbook of Creativity, New York, Cambridge University Press.

Klus-Stańska D. (2008a) Twórcze myślenie uczniów - mity, nieporozumienia, możliwości, „Problemy Wczesnej Edukacji”, nr 1 (7).

Klus-Stańska D. (2008b) Obszary zgody na twórczość dziecięcq we wczesnej edukacji w: Gdyby Einstein współcześnie chodził do szkoły... Dziecko i twórczość w pedagogice wczesnoszkolnej, E. Szatan, D. Bronk (red.), Gdańsk, Wydawnictwo UG, s. 57-68.

Kłosińska T. (2000) Droga do twórczości. Wdrażanie technik Celestyna Freineta, Kraków, Oficyna Wydawnicza „Impuls”.

Kłosińska T. (2013) Postawy nauczycieli wobec twórczości w: Kompetencje kreatywne nauczycieli wczesnej edukacji dziecka, I. Adamek, J. Bałachowicz (red.), Kraków, Oficyna Wydawnicza „Impuls”, s. 203-222.

Kocowski T. (1991) Szkice z teorii twórczości i motywacji, H. Sęk, A. Tokarz (red.), Kraków, Wydawnictwo UJ.

Konopczyński M. (2006) Twórcza resocjalizacja, Warszawa, Wydawnictwo Naukowe PWN. 
Kopciuch L. (2016) Kryzysy. Kreatywność i wartości, Lublin, Wydawnictwo UMCS.

Korniłowicz K. (1926/1976) Рomoc w tworzeniu jako zadanie pracy kulturalnej w: Pomoc społeczno-kulturalna dla młodzieży pracującej i dorosłych. Wybór pism, wstęp i oprac. O. Czerniawska, Wrocław, Ossolineum.

Kosieradzka A. (red.) (2013) Metody i techniki pobudzania kreatywności w organizacji i zarządzaniu, Kraków-Warszawa, Wydawnictwo edu-Libri.

Kozielecki J. (1996) Człowiek oświecony czy innowacyjny w: J. Kozielecki, Człowiek wielowymiarowy, Warszawa, Wydawnictwo Akademickie „Żak”.

Kozielecki J. (1997) Transgresje i kultura, Warszawa, Wydawnictwo Akademickie „Żak”.

Kozielecki J. (2001) Psychotransgresjonizm. Nowy kierunek psychologii, Wydawnictwo Warszawa, Wydawnictwo Akademickie „Żak”.

Kozielecki J. (2004) Społeczeństwo transgresyjne. Szansa i ryzyko, Warszawa, Wydawnictwo Akademickie „Żak”.

Kozielecki J. (2008) Psychologia w wielkim świecie, Warszawa, Wydawnictwo Akademickie „Żak”.

Krasoń K. (2005) Dziecięce odkrywanie tekstu literackiego. Kinestetyczne interpretacje liryki, Katowice, Wydawnictwo UŚ.

Krasoń K. (2013) Cielesność aktu tworzenia w teatrze ruchu, Kraków, Universitas.

Krasoń K., Mazepa-Domagała B. (2004) Przestrzenie sztuki dziecka, Katowice, Oficyna Wydawnicza „Librus”.

Kubicka D. (2000) Kontrowersje wokół pomiaru twórczości u dzieci, „Psychologia Wychowawcza", nr 2-3, s. 208-220.

Kubicka D. (2003) Twórcze działanie dziecka w sytuacji zabawowo-zadaniowej, Kraków, Wydawnictwo UJ.

Kuczyński J. (1976) Homo creator. Wstęp do dialektyki człowieka, Warszawa, „Książka i Wiedza".

Kujawiński J. (red.) (1990) Rozwijanie aktywności twórczej uczniów klas poczq̨tkowych. Zarys metodyki, Warszawa, WSiP.

Ligęza W. (2005) Badania nad reprezentacja poznawcza twórczości - test analogii w: Psychopedagogika działań twórczych, K. J. Szmidt, M. Modrzejewska-Świgulska (red.), Kraków, Oficyna Wydawnicza „Impuls”, s. 203-217. 
Ligęza W. (2017) Co dzieci wiedzq o twórczości i tworzeniu?, Kraków, Wydawnictwo PETRUS.

Limont W. (1984) Hipotetyczny model struktury uzdolnień plastycznych, „Psychologia Wychowawcza", nr 5, s. 542-552.

Limont W. (1994) Synektyka a zdolności twórcze, Toruń, Wydawnictwo UMK.

Limont W. (1996) Analiza wybranych mechanizmów wyobraźni twórczej, Toruń, Wydawnictwo UMK.

Limont W. (2005) Wykorzystywanie metaforycznego myślenia w edukacji ku twórczości w: W poszukiwaniu zastosowań psychologii twórczości, A. Tokarz (red.), Kraków, Wydawnictwo UJ, s. 93-123.

Lubińska-Kościółek E., Plutecka K. (red.) (2011) Stymulowanie potencjału twórczego osób z różnymi potrzebami edukacyjnymi, Kraków, Oficyna Wydawnicza „Impuls”.

Łukasik A. (1999) Zewnętrzne ograniczenia procesu twórczego, Rzeszów, Wydawnictwo WSP.

Magda-Adamowicz M. (2005) Twórczość dzieci we wczesnej edukacji, Legnica, Wyższa Szkoła Menedżerska.

Magda-Adamowicz M. (2012) Obraz twórczych pedagogicznie nauczycieli klas poczq̨tkowych, wyd. II zm., Toruń, Wydawnictwo Adam Marszałek.

Magyari-Beck I. (1990) An Introduction to the Framework of Creatology, "The Journal of Creative Behavior", 3, s. 151-160.

Magyari-Beck I. (1996) Creativity as a New (and Perhaps the Basic) Paradigm of Economic Psychology, "Society and Economy”, 1, s. 142-154.

Magyari-Beck I. (1999) Creatology w: Encyclopedia of Creativity, M. A. Runco, S. R. Pritzker (eds.), San Diego, Academic Press.

Mendecka G. (2003) Środowisko rodzinne w percepcji osób aktywnych twórczo, Częstochowa, Wydawnictwo WSP.

Mendecka G. (2009) Ojciec a twórczy rozwój dziecka w: Psychologia twórczości. Nowe horyzonty, S. Popek, R. E. Bernacka, C. W. Domański, B. Gawda, D. Turska, A. W. Zawadzka (red.), Lublin, Wydawnictwo UMCS, s. 216-225.

Mendecka G. (2015) Doświadczenia szkolne wybitnych twórców, „Psychologia Wychowawcza", t. I (LXIV), nr 8, s. 88-105. 
Nalaskowski A. (1998) Społeczne uwarunkowania twórczego rozwoju jednostki, wyd. 2, Warszawa, WSiP.

Nęcka E. (1995) Proces twórczy i jego ograniczenia, Kraków, Oficyna Wydawnicza „Impuls”.

Nęcka E. (2001) Psychologia twórczości, Gdańsk, Gdańskie Wydawnictwo Psychologiczne.

Nęcka E., Grohman M., Słabosz A. (2006) Creativity Studies in Poland w: The International Handbook of Creativity, J. C. Kaufman, R. J. Sternberg (eds.), New York, Cambridge University Press, s. 270-306.

Modrzejewska-Świgulska M. (2014) Twórczość codzienna w narracjach pedagogów, Łódź, Wydawnictwo UŁ.

Modrzejewska-Świgulska M. (red.) (2016) Biograficzne badania nad twórczościq̨. Teoria i empiria, Łódź, Wydawnictwo UŁ.

Parys K. (2013) Przestrzeń dla kreatywności uczniów z niepełnosprawnościq intelektualnq w stopniu lekkim, Kraków, Oficyna Wydawnicza „Impuls”.

Pietrasiński Z. (1969) Myślenie twórcze, Warszawa, PZWS.

Piirto J. (2004) Understanding Creativity, Great Potential Press, Inc., Scottsdale.

Pikała A., Sasin M. (2016) Arteterapia. Scenariusze zajęć, Łódź, Wydawnictwo UŁ.

Piotrowski K. T., Grohman M. (2003) „Zamot”, czyli skomplikowana sprawa. Analiza procesów syntezy pojęciowej w zadaniach odlingwistycznych w: Psychopedagogika działań twórczych, K. J. Szmidt, M. Modrzejewska-Świgulska (red.), Kraków, Oficyna Wydawnicza „Impuls”, s. 217-229.

Popek S. (2000) Kwestionariusz Twórczego Zachowania KANH, wyd. 2, Lublin, Wydawnictwo UMCS.

Popek S. (2001) Człowiek jako jednostka twórcza, Lublin, Wydawnictwo UMCS.

Popek S. (2010) Psychologia twórczości plastycznej, Kraków, Oficyna Wydawnicza „Impuls”.

Plucker J. A. (red.) (2017) Creativity \& Innovation. Theory, Research and Practice, Waco, Prufrock Press.

Płóciennik E. (2010) Stymulowanie zdolności twórczych dziecka. Weryfikacja techniki obrazków dynamicznych, Łódź, Wydawnictwo UŁ. 
Płóciennik E. (2016a) Rozwijanie mądrości dziecka. Koncepcje i wskazówki metodyczne, Łódź, Wydawnictwo UŁ.

Płóciennik E. (2016b) Rozwijanie mądrości w praktyce edukacyjnej. Scenariusze zajęć w przedszkolu i szkole podstawowej, Łódź, Wydawnictwo UŁ.

Płóciennik E. (2016c) Rozwijanie mądrości w praktyce edukacyjnej. Scenariusze zajęć dla młodzieży, Łódź, Wydawnictwo UŁ.

Przyborowska B. (2007) Struktury innowacyjne w edukacji, Toruń, Wydawnictwo UMK.

Przyborowska B. (2013) Pedagogika innowacyjności. Między teoriq a praktyka, Toruń, Wydawnictwo Naukowe UMK.

Pufal-Struzik I. (2006) Podmiotowe i społeczne warunki twórczej aktywności artystów, Kielce, Wydawnictwo Uczelniane Wszechnica Świętokrzyska.

Puślecki W. (1998) Wspieranie elementarnych zdolności twórczych uczniów, Kraków, Oficyna Wydawnicza „Impuls”.

Rudowski T. (2014) Studia nad arteterapiq $w$ ujęciu aksjologiczno-psychologicznym, Warszawa, Difin S.A.

Runco M. A. (2014) Creativity. Theories and Themes: Research, Development and Practice, 2 ed., San Diego, Academic Press.

Sajdak A. (2008) Edukacja kreatywna, Kraków, Wydawnictwo WAM.

Sawyer R. K. (2012) Explaining Creativity. The Science of Human Innovation, 2 ed., New York, Oxford University Press.

Schulz R. (1989) Nauczyciel jako innowator, Warszawa, WSiP.

Schulz R. (1990) Twórczość - społeczne aspekty zjawiska, Warszawa, PWN.

Schulz R. (1994) Twórczość pedagogiczna. Elementy teorii i badań, Warszawa, Instytut Badań Edukacyjnych.

Schulz R. (1996) Studia z innowatyki pedagogicznej, Toruń, Wydawnictwo UMK.

Sokół A. (2015) Zarzq̨dzanie twórczościq w organizacji. Koncepcja, metody i narzędzia, Warszawa, CeDeWu.

Sołowiej J. (1997) Psychologia twórczości, Gdańsk, Wydawnictwo Uniwersytetu Gdańskiego. 
Stasiakiewicz M. (1999) Twórczość i interakcja, Poznań, Wydawnictwo UAM.

Stróżewski W. (1983) Dialektyka twórczości, Kraków, PWM.

Stróżewski W. (2007) Dialektyka twórczości, wyd. 2, Kraków, Wydawnictwo Znak.

Strzałecki A. (1969), Wybrane zagadnienia psychologii twórczości, Warszawa, PWN.

Strzałecki A. (1989) Twórczość a style rozwiq̨zywania problemów praktycznych. Ujęcie prakseologiczne, Wrocław, Ossolineum.

Strzałecki A. (2003) Psychologia twórczości. Między tradycja a ponowoczesnościq, Warszawa, Wydawnictwo Uniwersytetu Kardynała S. Wyszyńskiego.

Suchodolski B. (1972) Labirynty współczesności, Warszawa, PIW.

Suchodolski B. (1975) Twórczość jako styl życia, „Studia Filozoficzne”, nr 10-11.

Suchodolski B. (1976) O działalności twórczej, „Studia Pedagogiczne”, t. XXVIII.

Suchodolski B. (1983) Twórczość - rzeczywistość, nadziej, wątpliwości w: B. Suchodolski, Wychowanie i strategia życia, Warszawa, WSiP.

Suchodolski B. (1999) Skąd i dokąd idziemy, Warszawa, MUZA.

Szmidt K. J. (2001a) Szkice do pedagogiki twórczości, Kraków, Oficyna Wydawnicza „Impuls”.

Szmidt K. J. (2001b) Twórczość i pomoc w tworzeniu w perspektywie pedagogiki społecznej, Łódź, Wydawnictwo UŁ.

Szmidt K. J. (2005) Dlaczego należy być twórczym? Rozważania o powodach istotnych uzasadniających sens treningu twórczości w: Trening twórczości w szkole wyższej, K. J. Szmidt (red.), Łódź, Wydawnictwo WSHE, s. 13-24.

Szmidt K. J. (2007) Pedagogika twórczości, Gdańsk, Gdańskie Wydawnictwo Psychologiczne.

Szmidt K. J. (2009a) W kierunku „kreatologii”. Charakterystyka najnowszych syntez wiedzy o twórczości (Weisberg, Runco, Sawyer) w: Psychologia twórczości. Nowe horyzonty, S. Popek, R. E. Bernacka, C. W. Domański, B. Gawda, D. Turska, A. W. Zawadzka (red.), Lublin, Wydawnictwo UMCS, s. 34-46.

Szmidt K. J. (2009b) Mity na temat twórczości dzieci i próba ich dekonspiracji w: Twórczość dzieci i młodzieży. Stymulowanie - badanie - wsparcie, K. J. Szmidt, W. Ligęza (red.), Kraków, OTE „Kangur”, s. 7-23. 
Szmidt K. J. (red.) (2009c) Metody pedagogicznych badań nad twórczością. Teoria i empiria, Łódź, Akademia Humanistyczno-Ekonomiczna.

Szmidt K. J. (2011) Twórczość typu fast food - krytyczna analiza poradników rozwoju kreatywności w: Podręczniki i poradniki. Konteksty - dyskursy - perspektywy, M. Chomczyńska-Rubacha (red.), Kraków, Oficyna Wydawnicza „Impuls”, s. 145-162.

Szmidt K. J. (2013a) Pedagogika twórczości, wyd. 2 poszerzone, Sopot, Gdańskie Wydawnictwo Psychologiczne.

Szmidt K. J. (2017a) Edukacyjne uwarunkowania rozwoju kreatywności, Łódź, Wydawnictwo UŁ.

Szmidt K. J. (2017b) Referat pt. „Teoria klasy twórczej Richarda Floridy po 15 latach - krytyka i obrona”, wygłoszony na II Ogólnopolskiej Konferencji Naukowej „Profesjonalizacja kreatywności” pt. „Kreatywne myślenie - kreatywne działanie”, Akademia Humanistyczno-Ekonomiczna w Łodzi, Wyższa Szkoła Przedsiębiorczości i Administracji w Lublinie, Lublin, 25-26.04.17.

Szopiński J. (2004) Kreatywność menedżerów a ich funkcjonowanie rodzinne, zawodowe i osobowościowe, Kraków, Wydawnictwo UJ.

Szulc W. (2011) Arteterapia. Narodziny idei, ewolucja teorii, rozwój praktyki, Warszawa, Difin S.A.

Szuman S. (1927) Sztuka dziecka. Psychologia twórczości rysunkowej dziecka, Warszawa, Książnica Atlas.

Szuman S. (1962) O sztuce i wychowaniu estetycznym, Warszawa, WSiP.

Tatarkiewicz W. (1975) Dzieje sześciu pojęć, Wrocław, Ossolineum.

Tokarz A. (1985) Rola motywacji poznawczej w aktywności twórczej, Wrocław, Ossolineum.

Tokarz A. (2005) Dynamika procesu twórczego, Kraków, Wydawnictwo UJ.

Tokarz A. (red.) (2005) W poszukiwaniu zastosowań psychologii twórczości, Kraków, Wydawnictwo UJ.

Trojanowska-Kaczmarska A. (1971) Dziecko i twórczość, Wrocław, Ossolineum.

Trzebiński J. (1978) Z badań nad uwarunkowaniami oryginalności myślenia, Wrocław, Ossolineum.

Trzebiński J. (1981) Twórczość a struktura pojęć, Warszawa, PWN. 
Ujwary-Gil A. (2004) Inwentyka, czyli kreatywność w biznesie. Wybrane zagadnienia, Nowy Sącz, WSB-NLU.

Uszyńska-Jarmoc J. (2003) Twórcza aktywność dziecka. Teoria - rzeczywistość - perspektywy rozwoju, Białystok, Wydawnictwo Uniwersyteckie Trans Humana.

Uszyńska-Jarmoc J. (2007), Od twórczości potencjalnej do autokreacji w szkole, Białystok, Wydawnictwo Uniwersyteckie Trans Humana.

Wojnar I. (1984) Teoria wychowania estetycznego, Warszawa, PWN.

Wojnar I. (2008) Pedagogika twórczej aktywności w: I. Wojnar, A. Piejka, M. Samoraj, Idee edukacyjne na rozdrożach XX wieku, Warszawa, Wydawnictwo Akademickie „Żak”, s. 21-39.

Wojnar K. (2016) Polska klasa kreatywna, Warszawa, Narodowe Centrum Kultury.

Wojtczuk-Turek A. (2008) Rozwijanie kompetencji twórczych, Warszawa, SGH.

Wróblewska M. (2005) Osobowościowe uwarunkowania postawy twórczej studentów, Białystok, Wydawnictwo Uniwersyteckie Trans Humana.

Wróblewska M. (2015) Kompetencje twórcze w dorosłości, Białystok, Wydawnictwo Uniwersyteckie Trans Humana.

Zborowski J. (1986) Rozwijanie aktywności twórczej uczniów, Warszawa, WSiP.

Zwiernik J. (1988) Twórcze uczestnictwo w kulturze w perspektywie edukacyjnej. Studium teoretyczno-empiryczne, Wrocław, Wydawnictwo Uniwersytetu Wrocławskiego.

Zwiernik J. (1996) Alternatywa w edukacji przedszkolnej. Studium teoretyczno-empiryczne, Wrocław, Wydawnictwo Uniwersytetu Wrocławskiego. 